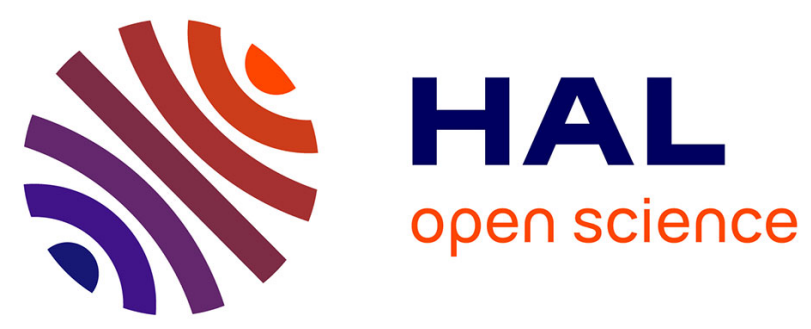

\title{
Sedimentary provenance from the evolving forearc-to-foreland Central Sakarya Basin, western Anatolia reveals multi-phase intercontinental collision
}

Megan A Mueller, Alexis Licht, Clay Campbell, Faruk Ocakoğlu, Gui G Akşit, Grégoire Métais, Pauline M C Coster, K. Christopher Christopher Beard, Michael H Taylor

\section{To cite this version:}

Megan A Mueller, Alexis Licht, Clay Campbell, Faruk Ocakoğlu, Gui G Akşit, et al.. Sedimentary provenance from the evolving forearc-to-foreland Central Sakarya Basin, western Anatolia reveals multi-phase intercontinental collision. Geochemistry, Geophysics, Geosystems, In press, 10.1029/2021GC010232 . hal-03546806

\section{HAL Id: hal-03546806 https://hal.science/hal-03546806}

Submitted on 28 Jan 2022

HAL is a multi-disciplinary open access archive for the deposit and dissemination of scientific research documents, whether they are published or not. The documents may come from teaching and research institutions in France or abroad, or from public or private research centers.
L'archive ouverte pluridisciplinaire HAL, est destinée au dépôt et à la diffusion de documents scientifiques de niveau recherche, publiés ou non, émanant des établissements d'enseignement et de recherche français ou étrangers, des laboratoires publics ou privés.

\section{(ㅇ)(1) $\$$}

Distributed under a Creative Commons Attribution - NonCommercial - NoDerivatives| 4.0 


\section{Sedimentary provenance from the evolving forearc-to-foreland Central Sakarya Basin,} western Anatolia reveals multi-phase intercontinental collision

Megan A. Mueller ${ }^{1}$, Alexis Licht ${ }^{1,2}$, Clay Campbell ${ }^{3}$, Faruk Ocakoğlu ${ }^{4}$, Gui G. Akşit ${ }^{1,5}$, Grégoire Métais $^{6}$, Pauline M. C. Coster ${ }^{7}$, K. Christopher Beard ${ }^{8,9}$, Michael H. Taylor ${ }^{3}$

${ }^{1}$ Department of Earth and Space Sciences, University of Washington, Seattle, Washington 98195, USA

${ }^{2}$ Aix-Marseille Université, CNRS, Centre de Recherche et d'Enseignement de Géosciences de l'Environnement (CEREGE), Aix-en-Provence, France

${ }^{3}$ Department of Geology, University of Kansas, Lawrence, Kansas 66045, USA

${ }^{4}$ Department of Geological Engineering, Eskişehir Osmangazi University, 26040 Eskişehir, Turkey

${ }^{5}$ Department of Earth Sciences, University of Oregon, Eugene, Oregon 97403, USA

${ }^{6}$ Centre de Recherches sur la Paléobiodiversité et les Paléoenvironnements, Muséum National d'Histoire Naturelle, 75005 Paris, France

${ }^{7}$ Réserve naturelle nationale géologique du Luberon, Apt, France

${ }^{8}$ Biodiversity Institute, University of Kansas, Lawrence, Kansas 66045, USA

${ }^{9}$ Department of Ecology and Evolutionary Biology, University of Kansas, Lawrence, Kansas 66045, USA

Corresponding author: Megan Mueller (megan.mueller@uconn.edu)

Key Points:

- Multi-phase intercontinental collision is identified in western Anatolia by sedimentary basin changes

- Sedimentary provenance change indicate collision was at $76 \mathrm{Ma}$, but significant thickskinned deformation was delayed until $54 \mathrm{Ma}$

- The 20 Myr duration of initial collision can be explained by three multi-stage mechanisms involving changes in plate coupling 
manuscript submitted to Geochemistry, Geophysics, Geosystems

\section{Abstract}

Collision between the Pontides and Anatolide-Tauride Block along the İzmir-AnkaraErzincan suture in Anatolia has been variously estimated from the Late Cretaceous to Eocene. It remains unclear whether this age range results from a protracted, multi-phase collision or differences between proxies of collision age and/or along strike diachroneity. Here, we leverage the Cretaceous-Eocene evolution of the forearc-to-foreland Central Sakarya Basin system in western Anatolia to determine when and how collision progressed. New detrital zircon and sandstone petrography results indicate that the volcanic arc was the main source of sediment to the forearc basin in the Late Cretaceous. The first appearance of Pontide basement-aged detrital zircons, in concert with exhumation of the accretionary prism and a decrease in regional convergence rates, indicates intercontinental collision initiated no later than $76 \mathrm{Ma}$. However, this first contractional phase does not produce advanced thick-skinned deformation and basin partitioning until ca. $54 \mathrm{Ma}$. We propose three non-exclusive and widely applicable mechanisms to reconcile the observed 20 Myr delay between initial intercontinental collision and thickskinned upper plate deformation: slab breakoff, relict basin closure north and south of the İAES, and underthrusting of progressively thicker passive margin lithosphere. These mechanisms highlight the links between upper plate deformation and plate coupling during continental collision.

\section{Plain Language Summary}

Key to understanding the interconnectedness of Earth's systems is unraveling feedbacks between climate, biology, and tectonic plate movements. This can only be resolved within a robust timeframe of tectonic events, including the collision of continents. Yet, the timing of collisions is difficult to determine. We present results from western Turkey where the history of oceanic basin closure and collision from 110 to 40 million years ago (Ma) is preserved in the sedimentary rock record. We identify three phases of oceanic closure (subduction) and continental collision. Subduction was active from at least $110 \mathrm{Ma}$ through $76 \mathrm{Ma}$ when sediment was derived from active volcanoes. At $76 \mathrm{Ma}$, continental deformation uplifted and eroded older rocks; this is the initial contact between colliding continents. The next phase of collision began at $54 \mathrm{Ma}$ when continental deformation separated the zone of sediment deposition into two basins. The 20-million-year collision duration can be explained by three changes to tectonic plate coupling. Together, we conclude that collision age discrepancies are representative of collision 
mechanics not a function of ill-fit comparisons between proxies. This long history of collision illuminates how the movement and amalgamation of small continents aided the migration and evolution of species in the Mediterranean.

Keywords: Anatolia, Neotethys, Intercontinental Collision, Detrital Zircon Geochronology

\section{Introduction}

Continental collisions across the Tethyan realm are striking by their protracted and polygenetic history, often resulting in significant discrepancies among proxies of collision age: 40 Myr for India-Asia (65-25 Ma; Ding et al., 2005; Hu et al., 2016; Kapp \& DeCelles, 2019; Najman et al., 2010) and 20 Myr for Arabia-Eurasia (Ballato et al., 2011; Cowgill et al., 2016; Darin et al., 2018; McQuarrie et al., 2003; Okay et al., 2010). Their unusual duration and complexity have even called into question the nature of the forces driving continental convergence (Alvarez, 2010; Becker \& Faccenna, 2011). This has led to multi-stage collision scenarios involving varying plate coupling at the subduction interface (Ballato et al., 2011; Beaumont et al., 1996; Tye et al., 2020) or the role of forearc, backarc, and other remnant basins as early buffers of deformation (Cowgill et al., 2016).

Collision age discrepancies are found in western and central Anatolia where continental collision between the Pontides and the Anatolide-affinity Tavşanlı Zone (TVZ) and Kırşehir Block along the İzmir-Ankara-Erzincan suture (İAES) closed the Neotethys Ocean (Figure 1; Okay \& Tüysüz, 1999; Şengör \& Yilmaz, 1981). Collision estimates along the İAES span 20 Myr from the Late Cretaceous to early Eocene based on ophiolite obduction and Barrovian metamorphism (Göncüoğlu et al., 2000; Seaton et al., 2009; Whitney et al., 2011), structural deformation (Lefebvre et al., 2013; Meijers et al., 2010; Okay et al., 2020; Şahin et al., 2019), magmatism (Dilek \& Altunkaynak, 2009; Ersoy, Akal, et al., 2017; Kasapoğlu et al., 2016), and sedimentary basin analysis (Kaymakci et al., 2009; Ocakoğlu et al., 2018; Okay, 2011). However, a model that encompasses the insights from all proxies is still missing.

To address this, we leverage the power of a $\sim 50$ Myr continuous depositional record from the Central Sakarya Basin system, a forearc-to-foreland basin directly north of the IAES. Integrating new sedimentary provenance data with previously published stratigraphic and provenance data reveals a multi-phase collisional evolution. We evaluate the timing of this 
manuscript submitted to Geochemistry, Geophysics, Geosystems

protracted collision in light of previously proposed multi-phase collision models for the Tethyan realm, including slab breakoff, relict basin closure, and passive margin underthrusting.

\section{Background}

The tectonic units in northwest Anatolia include, from north to south, the İstanbul Zone and Sakarya Zone (SKZ) of the Eurasian-affinity Pontides, the İzmir-Ankara-Erzincan suture zone (İAES), and the Tavşanlı Zone (TVZ) of the Gondwanan-affinity Anatolides (Figure 1; Okay \& Tüysüz, 1999; Şengör \& Yilmaz, 1981). The Pontides rifted from the Eurasian margin between 94 and 75 Ma by backarc spreading of the Black Sea (Akdoğan et al., 2017, 2019; Okay et al., 2013; Okay \& Nikishin, 2015), and formed an isolated microcontinent where faunal endemism prevailed until the late Paleogene (Métais et al., 2018). The SKZ, bound to the north by the Intra-Pontide suture zone, presently occupied by the North Anatolian Fault, comprises Sakarya Zone basement units and the forearc-to-foreland Central Sakarya Basin system (Figure 2). The Sakarya Zone continental basement is subdivided into two units: (1) the Central Sakarya Basement (also called Söğüt metamorphics) comprising Paleozoic paragneiss, schist, and amphibolite rocks intruded by Carboniferous granitoids called the Sögüt magmatics, Central Sakarya granite, or Sarıcakaya granitoid (Göncüoğlu et al., 2000; Ustaömer et al., 2012), and (2) the Permian-Triassic Karakaya Complex, partly metamorphosed clastic and volcanic rocks from either a rift or subduction-accretion complex setting (see Okay \& Göncüoglu, 2004). Remnants of the Late Cretaceous volcanic arc associated with northward subduction along the Pontide margin are exposed along the present-day Black Sea southern coast, north of the CSB and IntraPontide Suture (Figure 3; Keskin \& Tüysüz, 2018). However, pyroclastic flows, volcanogenic sandstones, and tuffs within the southern margin of the CSB are associated with Late Cretaceous submarine volcanism (Duru \& Aksay, 2002; Gedik \& Aksay, 2002; Ocakoğlu et al., 2018; Yilmaz et al., 2010). Additionally, the 83-70 Ma Beypazarı Granite is $<20 \mathrm{~km}$ south of the CSB (Figure 2; Helvaci et al., 2014; Okay et al., 2019, 2020; Speciale et al., 2012). The SKZ, İstanbul Zone, and TVZ contain Eocene (58-41 Ma) syn-collisional igneous rocks disputedly attributed to TVZ slab breakoff, lithospheric delamination, or anatexis of the lower crust (Altunkaynak, 2007; Altunkaynak et al., 2012; Dilek \& Altunkaynak, 2009; Ersoy, Akal, et al., 2017; Ersoy, Palmer, et al., 2017; Harris et al., 1994; van Hinsbergen et al., 2010; Kasapoğlu et al., 2016; Okay \& Satir, 2006; Ustaömer et al., 2009; Yildiz et al., 2015). The Central Sakarya Basin system is 
divided into the Jurassic-Eocene forearc-to-foreland Central Sakarya Basin (CSB; also called the Mudurnu-Göynük Basin) to the north and the Eocene broken foreland Sarıcakaya Basin (SB) to the south (e.g., Mueller et al., 2019; Ocakoğlu et al., 2007; Okay et al., 2001). The south-vergent basement-involved Tuzakl1-Gümele Thrust (also termed the Sögüt Thrust or Nallıhan Thrust) structurally partitioned the CSB by the early Eocene and formed the SB by flexural loading. Sakarya Zone basement units are exposed in the hanging wall (Duru \& Aksay, 2002; Gedik \& Aksay, 2002). The SB contains Ypresian-Lutetian terrestrial deposits that laterally transition to marine deposits in the east (Mueller et al., 2019; Okay et al., 2020; Şahin et al., 2019), and hosts one of the Eocene volcanic belts (Kasapoğlu et al., 2016; Yildiz et al., 2015). The fold-thrust belt is located within the CSB-SB system; W-E and SW-NE striking oblique thrust faults and folds deform Jurassic through Eocene units (Aksay et al., 2002; Şahin et al., 2019). Thin-skinned thrust faults in the CSB are likely positively inverted faults from a phase of SantonianCampanian extension (Ocakoğlu et al., 2018).

The SKZ is bound to the south by the İAES, a highly deformed accretionary complex containing obducted ophiolite slabs, ophiolitic mélange, and their metamorphic equivalents (e.g., Göncüoğlu et al., 2000, 2010). To the south, the TVZ is the passive margin of the northernmost Gondwana-derived Anatolide-Tauride Block (e.g., Okay, 2011; Okay et al., 1996). Platform carbonates and passive margin clastics were subducted and metamorphosed to blueschist facies between 92 and 83 Ma (e.g., Okay et al., 1998; Plunder et al., 2015; Sherlock et al., 1999; Whitney et al., 2011), exhumed sometime 85 to 60 Ma (Seaton et al., 2009; Sherlock et al., 1999; Whitney \& Davis, 2006), then underwent Barrovian-type metamorphism from 63 to $57 \mathrm{Ma}$ (Seaton et al., 2009; Whitney et al., 2011). The blueschist unit is tectonically overlain by suture zone units, including metamorphosed accretionary complexes (Plunder et al., 2013), ophiolitic mélange, and ophiolite slabs (Göncüoğlu et al., 2010; Okay et al., 2020). The western Anatolian ophiolites have metamorphic sole ages between 101 and 88 Ma (Dilek et al., 1999; Harris et al., 1994; Pourteau et al., 2019) and are cut by 92 to 90 Ma mafic dikes (Dilek et al., 1999), and, therefore, were obducted sometime after $~ 90$ Ma during pre-collisional TVZ subduction (Okay \& Whitney, 2010; Robertson et al., 2009). The blueschists and ophiolites are intruded by Eocene granodiorites (Harris et al., 1994) and unconformably overlain by lower Eocene shallow marine limestones and siliciclastic rocks (Baş, 1986; Özgen-Erdem et al., 2007) and lower-to-middle(?) Eocene continental deposits (Turhan, 2002). Herein we refer to TVZ subduction as the phase 
manuscript submitted to Geochemistry, Geophysics, Geosystems

when TVZ continental lithosphere was subducted beneath overlying oceanic lithosphere, whereas underthrusting refers to the phase when TVZ continental lithosphere was thrust beneath the upper plate Pontide continental lithosphere.

\section{Central Sakarya Basin System Stratigraphy}

Jurassic through Eocene sedimentation is preserved in the Central Sakarya Basin system (e.g., Aksay et al., 2002). Figure 4 displays stratigraphic columns with published stratigraphic ages for the Upper Cretaceous through Eocene units along two transects across the CSB (after Ocakoğlu et al., 2018).

Unconformably overlying Sakarya Zone basement units are the Jurassic through Lower Cretaceous series of shallow water platform carbonates (Bilecik Fm.), pelagic micrites and calciturbidites (Soğukçam Fm.), and interbedded volcanics (Mudurnu Fm.; Altiner et al., 1991; Genç \& Tüysüz, 2010). The CSB formed as a rift basin, as indicated by overall basin deepening trend and bimodal Jurassic volcanism (Altiner et al., 1991; Genç \& Tüysüz, 2010; Göncüoğlu et al., 2000), bounded by two branches of the Neotethys Ocean: the Intra-Pontide Ocean to the north and the İzmir-Ankara Ocean to the south. There is uninterrupted Jurassic through Paleocene sedimentation in the eastern CSB (e.g., Nallihan transect in Figure 4), whereas much of the Albian through Lower Campanian section is missing in the western CSB (e.g., Okay et al., 2001). The Albian-Lower Campanian sequence includes the Yenipazar and Seben Fms. siliciclastic turbidites and pelagic mudstones that are interfingered with the Üzümlü Mbr. volcaniclastics and submarine lava flows, Değirmenözü Fm. pelagic carbonates, and Eymür Mbr. shallow marine clastic wedge and submarine canyon fill (Ocakoğlu et al., 2018). Asymmetrical ripples, gravel and flute casts in Campanian-Maastrichtian deposits indicate paleocurrent directions to the NNW, N, NE, and rarely W (Ocakoğlu et al., 2018). The shallow marine to deltaic Paleocene Taraklı Fm. conformably overlies the Yenipazar Fm. Cross beds and groove casts indicate paleocurrent directions to the NW and NE (Ocakoğlu et al., 2018). The shelf edge was likely located near the Nallihan section, where deltaic progradation began in early Paleocene times, then deltaic sands and muds reached the northern Taraklı section in the late Paleocene where sedimentation rates were briefly extremely rapid (Ocakoğlu et al., 2018). 
In the western Yenipazar section, the Kızılçay Fm. unconformably overlies the Yenipazar Fm., whereas in the eastern Nallıhan section, the Kızılçay Fm. conformably overlies the Taraklı Fm. The shoaling sequence is overlain by coal beds, cross bedded sandstones, and caliches of the Kızılçay Fm. (Ocakoğlu et al., 2018). Ostracod fauna indicate a Ypresian age (Ocakoğlu et al., 2018). In the proximal Nallıhan and Yenipazar sections, fluvial conglomerates contain clasts of reworked Upper Cretaceous strata and marine microfauna, and clast imbrications, cross beds, and channel geometries indicate paleocurrent directions to the NW and NE. The Kızılçay Fm. grades northward into the Yenipazar Fm. where prograding delta front sandstones are present in the distal Akdoğan section (Ocakoğlu et al., 2018). The coarse marine clastics, alternating sands and muds, and turbidite deposits of the conformable Kabalar Mbr., Güvenç Fm., Çataltepe Fm., and Halidiye Fm. sequence records a Ypresian through early Bartonian marine transgression (Ocakoğlu et al., 2012, 2018; Şafak et al., 2015). Groove and flute casts and asymmetrical ripples in the Halidiye Fm. indicate paleocurrent directions to the NW, NE, and rarely $\mathrm{W}$ and $\mathrm{E}$ (Ocakoğlu et al., 2018). The late Lutetian maximum flooding surface is recorded in sedimentary basins across the Black Sea region, including Anatolia, Crimea and the Caucasus (e.g., Licht et al., 2017; Lygina et al., 2016; MTA, 2002; Özcan et al., 2019; Racey, 2001). The Gemiciköy Fm. comprises mudstone and cross-bedded sandstones that coarsen upward to fluvial conglomerates with clasts of reworked Cretaceous-Paleocene units (Ocakoğlu et al., 2007); it only crops out north of Yenipazar where it conformably overlies the Güvenç Fm. (Gedik \& Aksay, 2002; Ocakoğlu et al., 2018).

The Sarıcakaya Basin fill begins with Ypresian alluvial fan deposits that unconformably overlie Permian-Triassic Karakaya Complex rocks in the west and Jurassic-Cretaceous sedimentary units in the east (Campbell, 2017; Mueller et al., 2019; Şahin et al., 2019). The lower to middle Eocene strata include alternating overbank, conglomeratic fluvial channel, and lacustrine deposits interpreted to reflect changing accommodating due to flexural loading from the Tuzakl1-Gümele Thrust (Mueller et al., 2019). Detrital zircon ages and clast compositions indicate that the SB received sediment from the İAES mélange, Karakaya Complex, and exposed Sakarya Zone crystalline basement in Ypresian-Lutetian times (Mueller et al., 2019). Therefore, the basement-involved Tuzakl1-Gümele Thrust partitioned the CSB and formed the Sarıakaya Basin by ca. 54 Ma. The eastern SB contains Ypresian marine shales and Lutetian shoreface and shallow marine deposits with nummulites sp. (Okay et al., 2020; Şahin et al., 2019). 
manuscript submitted to Geochemistry, Geophysics, Geosystems

\section{Methods}

We collected 37 sandstone samples from Cretaceous through Eocene strata in the CSB and 2 gneiss samples from the Central Sakarya Basement (Table 1). The sandstone samples were collected along five published measured sections from two proximal (south) to distal (north) transects through the CSB (Figure 4; Ocakoğlu et al., 2018). The provenance of sandstone samples was evaluated using detrital zircon (DZ) U-Pb geochronology and sandstone petrography.

For the new CSB samples, heavy mineral separation, analysis, and data reduction followed the University of Washington TraceLab protocol (Licht et al., 2018; Shekut \& Licht, 2020). Zircons were separated following standard heavy mineral separation procedures. A minimum of 140 grains per sample were mounted with reference materials, imaged in a backscattered electron detector with a scanning electron microscope, and analyzed using a quadrupole laser ablation-inductively coupled plasma-mass spectrometer (LA-ICP-MS). The data were reduced in Iolite using the Geochron Data Reduction Scheme (Paton et al., 2011). Individual zircons with abnormal patterns in raw signal intensity, $>20 \%$ discordance, or $>5 \%$ reverse discordance are reported in the supporting information but are excluded from interpretations (following Gehrels, 2012, 2014). All zircon U-Pb ages are presented uncorrected for common lead (Shekut \& Licht, 2020), and the data are presented as probability density functions and kernel density estimates with an optimized fixed bandwidth, all plotted using detritalPy (Sharman et al., 2018).

The ages of the sedimentary samples were constrained by published biostratigraphic and volcanic zircon U-Pb ages along the measured sections (Campbell, 2017; Ocakoğlu et al., 2018). Maximum depositional ages, calculated using the youngest cluster of 2 or more ages with overlapping 2s uncertainties (Sharman et al., 2018), are included in Dataset S1 but do not provide any new age constraints.

We characterize the zircon age signature of potential sediment sources using new Central Sakarya Basement bedrock samples and published Central Sakarya Basement, Karakaya Complex, and İAES bedrock and modern river samples (Table 1). We also include crystallization ages of Cretaceous-Eocene plutons in central and eastern Anatolia compiled in Schleiffarth et al. (2018). The two new basement samples and one CSB sample (15YP15) were 
analyzed at the University of Kansas Isotope Geochemistry Laboratory following the analytical protocol outlined in Campbell (2017). Zircons were separated following standard methods, mounted with international standards, and analyzed in a high resolution sector-field LA-ICP-MS. Data were reduced in Iolite (Paton et al., 2011) and ET_Redux (McLean et al., 2016) and are presented uncorrected for common lead.

We further characterize sedimentary provenance using petrographic analysis of sandstone samples $(\mathrm{N}=31)$. Thin sections were made by National Petrographic Service, Inc. and at least 400 framework grains per sample were point counted according to the Gazzi-Dickinson method (Dickinson, 1985). The new CSB sandstone modal composition data are presented as ternary diagrams (Triplot; Graham \& Midgley, 2000) and interpreted following standard source fields (Dickinson, 1985; Dickinson \& Suczek, 1979).

\section{Provenance Results}

New DZ data $(\mathrm{N}=19 ; \mathrm{n}=3188)$ are presented with published DZ data $(\mathrm{N}=13, \mathrm{n}=1457)$. Detrital zircon distributions of potential sediment source samples and basin samples are given in Figure 5 and Figure 6, respectively. To facilitate comparison, distributions are colored according to the ages of known late Neoproterozoic through Eocene plutonic outcrops across the Black Sea region (Figure 3). Sandstone petrography results of new CSB samples are displayed in Figure 7.

New $(\mathrm{n}=169)$ and published $(\mathrm{n}=1763)$ bedrock, detrital, and modern river zircon U-Pb ages characterize the zircon signature of basement units and volcanic arcs (Figure 5; Table 1). The central and eastern Anatolian volcanic arc is characterized by 30-56 Ma and 67-99 Ma age peaks. The Karakaya Complex samples are characterized by 200-250 and 325 Ma populations, and, additionally, the modern river sample (17RIVER01) draining the İAES contains minor Eocene, Late Cretaceous, Triassic, and Paleozoic populations. The Central Sakarya Basement bedrock samples exhibit a prominent $\sim 325 \mathrm{Ma}$ peak, and the oldest samples include 375-500 Ma age populations; the metasedimentary sample ('SgtMeta' from Ustaömer et al., 2012) contains a range of Proterozoic-Archean zircons with peaks centered around $600 \mathrm{Ma}, 1000 \mathrm{Ma}, 2000 \mathrm{Ma}$, and $2650 \mathrm{Ma}$. The absence of Precambrian-aged zircons in most Central Sakarya Basement 
samples is likely due to sampling bias as most of the samples are orthogneiss and granitoids, with only one metasedimentary sample ('SgtMeta’ from Ustaömer et al., 2012).

New ( $\mathrm{n}=3199)$ and published $(\mathrm{n}=1457)$ CSB and SB detrital zircon ages (Figure 6) and new sandstone petrography results (Figure 7) characterize sedimentary provenance. The oldest CSB samples are Cenomanian to lower Campanian in age and are characterized by a major 76110 Ma peak; few zircons are older than $110 \mathrm{Ma}(\mathrm{n}=22 / 660,3 \%)$. These samples plot in the volcanic arc and recycled orogen fields. Samples younger than the lower Campanian have prominent Late Cretaceous (67-110 Ma) and Carboniferous ( 325 Ma) peaks. The youngest CSB samples also contain a prominent Eocene peak ( 41-58 Ma). About half of these samples have major or minor Triassic ( 250 Ma), Devonian (375-400 Ma), and Proterozoic peaks around 600 Ma, 1000 Ma and 2000 Ma. The Sarıcakaya Basin samples have a similar distribution of DZ ages, yet for many SB samples, the pre-Cretaceous populations are more abundant than in the CSB.

\section{Three Phase Evolution of the Central Sakarya Basin System}

We subdivide the samples into three age groups based on major changes in sedimentary provenance and basin evolution (Figure 8). The sample ages, and therefore sample groups, are constrained by published biostratigraphy, primarily planktonic foraminifera, one volcaniclastic $\mathrm{U}-\mathrm{Pb}$ age, and one maximum depositional detrital zircon U-Pb age (Ocakoğlu et al., 2018). The ages of the SB samples are constrained by volcaniclastic U-Pb ages (Mueller et al., 2019). Maximum depositional ages of the new detrital zircon samples do not provide new chronologic constraints (Dataset S1).

All CSB and SB DZ ages from 150 to $30 \mathrm{Ma}$ are combined and plotted alongside simplified composite stratigraphic columns (Figure 9). We interpret the combined DZ ages from 150 to $30 \mathrm{Ma}$ as the magmatic arc tempo of the Anatolian arc (Paterson \& Ducea, 2015). The apparent magmatic lulls at 67-58 Ma and starting at $41 \mathrm{Ma}$ are consistent with the 72-58 Ma and 40-20 Ma magmatic lulls in central and eastern Anatolia (Schleiffarth et al., 2018). 
Phase 1 includes Turonian through lower Campanian (94-76 Ma) DZ samples from the eastern CSB. This phase is characterized by a major 76-110 Ma peak; few zircons are older than $110 \mathrm{Ma}(\mathrm{n}=22 / 660 ;$ Figure 8). Samples plot in the volcanic arc and recycled orogen fields (Figure 7). Given the volcanic arc sediment compositions, the prevalence of Late Cretaceous zircon ages, and the proximity to plutons and submarine volcanism in the southern Sakarya Zone, Phase 1 strata are presumably composed of first-cycle detritus derived from the nearby Late Cretaceous volcanic centers. The brief magmatic lull at $88 \mathrm{Ma}$ (Figure 9) could be the signal of pre-collisional TVZ subduction. This $34 \mathrm{Myr}$ phase is not associated with any significant changes in depositional environment, accumulation rate (Ocakoğlu et al., 2018) or sedimentary provenance. In Phase 1, the CSB was a forearc basin fed by the Late Cretaceous volcanic belt.

\subsection{Phase 2: Initial Intercontinental Collision}

Phase 2 includes the middle Campanian through lower Eocene samples (76-54 Ma). Phase 2 is defined by a major change in provenance: the appearance of Paleozoic-Precambrian zircons (Figure 8). The start of Phase 2 at $76 \mathrm{Ma}$ is determined by the oldest samples with preMesozoic DZs. In the Nallihan section, the oldest samples in this phase are between 77 Ma and $76 \mathrm{Ma}$ based on planktonic foraminifera, and in the Göynük section the oldest Phase 2 sample has a published maximum depositional age of $76.4 \pm 1.7$ Ma based on the youngest 19 zircons (Ocakoğlu et al., 2018).

The Phase 2 sandstone compositions plot in the recycled orogen and volcanic arc fields and evolve toward increasing quartz and sedimentary and metamorphic lithic compositions (Figure 7). DZ samples are generally characterized by 67-90 Ma, 300-450 Ma and 550-700 Ma peaks (Figure 8). The presence of Carboniferous zircons alone or in tandem with Devonian to Proterozoic zircons are either first-cycle or poly-cyclic zircons from the Central Sakarya Basement, which is presently exposed in the hanging wall of the Tuzakl1-Gümele Thrust (Figure 2). The Triassic and Carboniferous age doublet is distinctively Karakaya Complex in origin (Figure 5) and, given the absence of Triassic igneous rocks across Anatolia (Figure 3), the presence of this doublet likely indicates sediment sourced from the Karakaya Complex rather than from both Triassic and Carboniferous igneous rocks (e.g., samples 18TBTG and 18TK01). The absence of deposition in the flexural SB before $~ 53 \mathrm{Ma}$ indicates that the Tuzakl1-Gümele 
323 Thrust likely did not expose basement rocks in Phase 2. Therefore, we propose that the 324 basement-age zircons and evolution toward quartz- and sedimentary lithic-rich compositions indicate an unroofing sequence in which poly-cyclic basement-aged zircons appeared in the basin. It is uncertain exactly where sediment recycling occurred or which structures were active, but we suggest it was a southern source for two reasons: (1) Increased mafic/felsic element ratios (i.e., $\mathrm{Ni} / \mathrm{Zr}, \mathrm{Ni} / \mathrm{Y}, \mathrm{Cr} / \mathrm{Zr}$ ) in the distal İsmailler section at ca. $73 \mathrm{Ma}$ show the input of ophiolitic material into the CSB, pinpointing the area of exhumation to the IAES where Late PaleozoicMesozoic ophiolitic and subduction-accretion units are exposed today. (2) Paleocurrent directions indicating flow from the SW-SE to NE-NW (Ocakoğlu et al., 2018). Together this indicates that at $76 \mathrm{Ma}$, the southern margin of the SKZ, including the IAES accretionary complex, began uplifting, exhuming, and creating south-to-north flowing transverse drainage systems.

We propose that uplift of the southern Pontide margin marks the onset of initial intercontinental collision. A $76 \mathrm{Ma}$ age of initial collision is supported by a decrease in convergence rates from $28 \mathrm{~mm} / \mathrm{yr}$ at 110-76 Ma to $5 \mathrm{~mm} / \mathrm{yr}$ from $76 \mathrm{Ma}$ onwards (rates calculated from plate reconstructions based on paleomagnetic and kinematic data in van Hinsbergen et al., 2020). Moreover, evolved $\varepsilon \mathrm{Hf}$ values in 85-70 Ma detrital zircons indicate either crustal thickening, lower plate continental underthrusting, or arc migration into evolved continental crust (Campbell, 2017). Lastly, Okay et al. (2020) interpret the 74 Ma onset of the major dextral transpressional Sakarya Shear Zone as initial collision.

Exhumation and underthrusting continued through Phase 2 when the CSB records northward prograding deltas at $61 \mathrm{Ma}$, a major unconformity in the proximal (southern) basin, a lowstand systems tract, the transition from flysch to molasse, and an order of magnitude increase in accumulation rates (Açıkalın et al., 2016; Ocakoğlu et al., 2007, 2018). These CSB changes coincide with a 67-58 Ma magmatic lull (Figure 8), and 63-57 Ma Barrovian metamorphism of the TVZ to greenschist and amphibolite facies (e.g., Whitney et al., 2011) and subsequent TVZ exhumation at $60 \mathrm{Ma}$ as indicated by white mica ${ }^{40} \mathrm{Ar} /{ }^{39} \mathrm{Ar}$ cooling ages (Seaton et al., 2009).

\subsection{Phase 3: Thick-Skinned Deformation and Foreland Basin Partitioning}

The start of Phase 3 is defined by the onset of deposition in the SB, which is dated to 52.4 $\pm 0.6 \mathrm{Ma}$ by a volcaniclastic bed at the base of the Paleogene series in the SB (Campbell, 2017; 
Mueller et al., 2019). Thus, the start of Phase 3 is associated with the onset of basin partitioning and the first clear evidence for advanced thick-skinned deformation. The onset of basementinvolved deformation likely preceded the beginning of basin partitioning and SB deposition by several million years, but at this point the oldest SB deposits are the best minimum age estimate for the onset of thick-skinned deformation. Eocene SB DZ samples are generally characterized by a 46-58 Ma peak along with 200-250 Ma, 325 Ma, 375-400 Ma, $600 \mathrm{Ma}, 1000 \mathrm{Ma}, 2000 \mathrm{Ma}$ and 2600 Ma peaks. Paleozoic to Proterozoic detrital zircon ages and clasts of quartz, mica and gneiss in the SB indicate that the Central Sakarya Basement, which was exposed in the hanging wall of the thrust, was a sediment source (Mueller et al., 2019). In addition, the 46-58 Ma peak and 200-250 and $325 \mathrm{Ma}$ doublet indicate that the SB received sediment from the Eocene volcanic belt within the SB and the Karakaya Complex, respectively (Mueller et al., 2019).

In the CSB, the increase in sedimentary lithics (Figure 7) along with negligible changes in DZ age spectra from Phase 2 to Phase 3-except for the appearance of 58-41 Ma zircons (Figure 8) - are consistent with continued sediment recycling and no major change in CSB provenance through the middle Eocene. The absence of the Karakaya Complex Triassic and Carboniferous age doublet and the scarcity of Silurian-Precambrian zircons in middle to upper Eocene CSB samples could point to disconnected CSB and SB depocenters. CSB-SB partitioning is roughly coeval with the resumption of deposition in the southwestern CSB and the 58-54 Ma transition from marine to continental facies and prograding clastic wedges (Ocakoğlu et al., 2018). Sediment recycling and general northward-directed drainages (Ocakoğlu et al., 2018) suggest that Phase 1 and 2 deposits were unroofed along the Tuzakl1-Gümele Thrust hanging wall and recycled into the CSB during Phase 3. Therefore, during Phase 3, deformation and exhumation propagated north of the İAES; basement-involved shortening (Şahin et al., 2019) structurally partitioned the SB and CSB foreland along the Tuzakl1-Gümele Thrust (Figure 2; Mueller et al., 2019). Seaways persisted into Phase 3 as indicated by Ypresian-Lutetian marine deposition in the eastern SB (Okay et al., 2020; Şahin et al., 2019) and Lutetian-Priabonian marine deposition in the distal (northern) CSB (e.g., Ocakoğlu et al., 2018), which suggests there was not significant regional surface uplift or crustal thickening during Phase 3 (54-38 Ma). 


\section{Implications for Geodynamic Mechanisms Controlling Collisional Deformation}

382

This section explores the possible geodynamic mechanisms that could explain a $20 \mathrm{Myr}$ multi-phase collision along the İAES. Multi-phased, "soft-hard" collisions have been proposed numerous times in the Tethyan domain (e.g., Ballato et al., 2018; Beaumont et al., 1996; Darin et al., 2018; Jagoutz et al., 2016; Kaymakci et al., 2009; Pourteau et al., 2016; Tye et al., 2020) and worldwide. These scenarios are based on a variety of mechanisms: subduction of a highly extended lower plate oceanic and continental lithosphere (van Hinsbergen et al., 2011, 2012), arc-continent collision (Jagoutz et al., 2016; Martin et al., 2020), slab breakoff (DeCelles et al., 2011; Sinclair, 1997), relict basin closure (Cowgill et al., 2016), and increased lower plate lithospheric thickness (Ballato et al., 2011; Soret et al., 2021). One or a combination of these scenarios could explain the protracted nature of intercontinental collision in western Anatolia, including the thick-skinned deformation and basin partitioning at $54 \mathrm{Ma}$.

Several mechanisms for protracted Tethyan collisions are not applicable in western Anatolia. Discrepancies between shortening and convergence led to several geodynamic mechanisms for protracted and multi-stage India-Asia collision (e.g., Hu et al., 2016; Kapp \& DeCelles, 2019 and references therein), such as a wide lower plate lithosphere (i.e., Greater India; van Hinsbergen et al., 2011, 2012) and initial collision of an intra-oceanic arc (Jagoutz et al., 2015, 2016; Martin et al., 2020). While there likely was a wide pre-collisional lower plate TVZ lithosphere and possibly an intra-oceanic arc (Göncüoğlu et al., 2000, 2010; Sarıfakıŏlu et al., 2009, 2017), the most recent plate reconstructions require only a few hundred kilometers between the SKZ and TVZ in the early Campanian (van Hinsbergen et al., 2020). Therefore, these geodynamic mechanisms invoked to explain upper plate shortening deficits and thousands of kilometers of distance between continental domains during initial collisional deformation are not pertinent in western Anatolia. In the remaining part of the discussion, we focus on the three mechanisms that are the most viable for SKZ-TVZ collision.

\subsection{Slab Breakoff}

Slab breakoff is a mechanism commonly employed to explain coeval surface uplift, extension and magmatism (von Blanckenburg \& Davies, 1995; Davies \& von Blanckenburg, 1995), although its prevalence in the geologic past and its genetic connection to magmatism is questioned (Garzanti et al., 2018; Niu, 2017). In western Anatolia, slab breakoff can explain the 
411 timing and geochemical signature of 58-40 Ma magmatism (Altunkaynak et al., 2012; Dilek \& 412 Altunkaynak, 2009; Ersoy, Akal, et al., 2017; Ersoy, Palmer, et al., 2017; Harris et al., 1994; 413 Kasapoğlu et al., 2016). However this interpretation is debated for four main reasons (Ustaömer 414 et al., 2009; see also Mueller et al., 2019; Okay \& Whitney, 2010; Okay \& Satir, 2006; van 415 Hinsbergen et al., 2010). (1) The TVZ slab was subducted to mantle depths in the Late 416 Cretaceous and the exhumation of blueschists in the Campanian-Maastrichtian suggests slab 417 breakoff was in the Late Cretaceous not Eocene (e.g., Okay \& Satir, 2006). (2) Geodynamic 418 models of slab breakoff predict $>1.5 \mathrm{~km}$ of surface uplift across several hundreds of kilometers across-strike (Göğüş et al., 2016). Yet, across the $<150 \mathrm{~km}$ İAES and CSB width (Figure 2), Paleocene-Eocene marine deposition in the CSB and SB indicates there was not significant surface uplift. (3) Magmatism was contemporaneous across three parallel volcano-plutonic belts at the northern margin of the CSB, bisecting the SB, and in the TVZ (e.g., Ersoy, Akal, et al., 2017; Ersoy, Palmer, et al., 2017; Harris et al., 1994; Kasapoğlu et al., 2016). (4) There was early Eocene contractional deformation in the SB and no evidence for extension (Mueller et al., 2019; Şahin et al., 2019). Slab breakoff has been inferred in extensional sedimentary basins based on the observation of alternating clastic and lacustrine deposits, an overall fining-upward sedimentary succession, high sedimentation rates, and an absence of contractional growth structures (DeCelles et al., 2011; Leary et al., 2016). Although the SB contains alternating clastic floodplain and lacustrine limestone deposits and no contractional growth strata, the presence of basement-aged zircons and clasts of quartz, mica and gneiss in coarse-grained fluvial deposits indicate that the Central Sakarya Basement was exposed in the hanging wall of the Tuzakl1Gümele Thrust in the early Eocene (Mueller et al., 2019). The slab break-off model remains a popular interpretation for Eocene magmatism; other explanations include lithospheric delamination (van Hinsbergen et al., 2010; Pourteau et al., 2013), arc volcanism from a different subduction zone system (Okay \& Satir, 2006), and mid-to-late Eocene orogenic collapse and extension (Ustaömer et al., 2009). We note that an amagmatic slab breakoff (Garzanti et al., 2018; Niu, 2017) occurring 10 Myr after initial collision, during the 67-58 Ma magmatic lull and Yenipazar section angular unconformity, could partly solve these issues and provide a mechanism to increase plate coupling and contractional deformation and facilitate juvenile magmatism (Figure 10a). 
In both the Arabia-Eurasia and India-Asia collisions, the initial collision of upper plate island arcs or continental terranes with the lower plate continental lithosphere results in upper plate backarc basin closure (e.g., Cowgill et al., 2016; Jagoutz et al., 2015; Kapp \& DeCelles, 2019). Initial Arabian collision is inferred from the coeval ca. 36 Ma magmatic lull and switch from extension to contraction in the Alborz Mountains of Iran (Ballato et al., 2011), and increased exhumation rates in the eastern Taurides (Darin et al., 2018) and central Pontides (Ballato et al., 2018). Yet initial foreland basin sedimentation (Ballato et al., 2011), slowed convergence rates (McQuarrie et al., 2003), and increased exhumation near the Bitlis suture zone (Okay et al., 2010) was delayed until at 20-17 Ma. Cowgill et al. (2016) suggest that significant upper plate deformation from the Arabia-Eurasia collision was delayed by $\sim 15-20$ Myr due to northward jumping deformation. In this scenario, collisional stress was transferred through the lithosphere and closed several upper plate basins (Cowgill et al., 2016). Eocene-Oligocene Arabian collision along the Bitlis-Zagros suture (e.g., Koshnaw et al., 2019; McQuarrie et al., 2003; McQuarrie \& van Hinsbergen, 2013) initiated subduction in the backarc basin between the Lesser and Greater Caucasus (e.g., Avdeev \& Niemi, 2011); then, completed backarc basin closure around 5 Ma produced a 10-fold increase in Greater Caucasus exhumation rates (Avdeev $\&$ Niemi, 2011) coincident with foreland basin erosion and non-deposition, mixing of sediment from the upper and lower plates, and provenance signatures of progressive crustal exhumation (e.g., Tye et al., 2020).

In line with this relict basin closure scenario, major collisional deformation from initial TVZ-SKZ underthrusting could be delayed by >20 Myr due to the closure of relict basins to the north or south of the IAES (Figure 10b). The closure of the Intra-Pontide suture zone is a strong candidate to explain this delay because the timing of suturing remains unclear, with proposed ages spanning from the Early Cretaceous (Akbayram et al., 2013), to the Late CretaceousPaleocene (Di Rosa et al., 2019; Göncüoğlu et al., 2000; Özcan et al., 2012; Robertson \& Ustaömer, 2004), and to the Paleocene-Eocene (Akbayram et al., 2016; Göncüoğlu et al., 2014; Okay et al., 1994). Major contractional deformation could also be delayed by the hypothesized southward-jumping subduction zones synchronously or sequentially facilitating the closure of Neotethyan oceanic basins between Anatolide and Tauride terranes south of the İAES (Pourteau et al., 2013, 2016). Resumed or increased continental underthrusting at $54 \mathrm{Ma}$ along the İAES could partly explain the renewal of magmatism without explaining its regional distribution. The 
lack of consensus on the history of Intra-Pontide rifting and suturing makes it difficult to assess the applicability of this mechanism.

\subsection{Increasing Lithospheric Thickness of the Lower Plate}

Another two-stage collision scenario invoked for Tethyan collisions involves the underthrusting of increasing thickness of lower plate passive margin lithosphere (e.g., Ballato et al., 2011; Darin et al., 2018; Soret et al., 2021). In the Himalayan sector, the initial collision of India with Asia is generally accepted as 60-55 Ma when the final vestiges of Neotethyan oceanic crust were subducted (Hu et al., 2016 and references therein). In northern Pakistan, Barrovian metamorphism from 47 to $38 \mathrm{Ma}$ is coincident with the formation and exhumation of eclogites (Soret et al., 2021), a >50\% decrease in convergence rates at 50-45 Ma (van Hinsbergen et al., 2011), and increased exhumation in the Himalaya starting around 35 Ma (Ding et al., 2016). Following oceanic basin closure, Soret et al. (2021) identify the first phase of collision as a period of "continental subduction," which is the slow underthrusting of thinned Indian passive margin lithosphere beneath Asia. Continental subduction is expressed as Barrovian metamorphism and the accommodation of convergence by underplating and tectonic stacking (Soret et al., 2021). Then, a second collision phase, "collision initiation," began ca. 38 Ma when increased mechanical coupling between India and Asia significantly increased transpressional deformation (i.e., Main Mantle thrust, Karakorum fault), exhumation, uplift, and erosion rates (Soret et al., 2021).

Therefore, multi-phase collision in western Anatolia could be attributed to the arrival of progressively thicker, buoyant TVZ continental lithosphere beneath the SKZ (Figure 10c). At 76 Ma, the initial continental subduction," or "soft" collision, of thinned passive margin lithosphere locked the subduction zone megathrust, triggered upper plate shortening, and exhumed the accretionary prism (Beaumont et al., 1996; Tye et al., 2020). The appearance of basement-aged zircons in the CSB at $76 \mathrm{Ma}$ is closely followed by a regional unconformity (Ocakoğlu et al., 2007), magmatic lull (67-58 Ma), TVZ Barrovian metamorphism (63-57 Ma; e.g., Whitney et al., 2011), and TVZ exhumation (60 Ma; Seaton et al., 2009). Subsequent thick-skinned deformation and basin partitioning by 54 Ma (Mueller et al., 2019; Şahin et al., 2019) would represent the final "collision initiation", or "hard collision," defined by the arrival of full-thickness continental lithosphere along the subduction zone and a more substantial plate coupling manifested as 
widespread regional contractional deformation. A convergence rate of $\sim 5 \mathrm{~mm} / \mathrm{yr}$ from 76 to 54 Ma (van Hinsbergen et al., 2020) predicts $\sim 110 \mathrm{~km}$ of TVZ underthrusting, which is less than estimates for the amount of underthrust thinned, passive margin Arabian lithosphere ( 400-480 km; Ballato et al., 2011; Darin et al., 2018). This mechanism reasonably explains the collisional evolution of the İAES in western Anatolia.

\subsection{Geodynamic Influence on Mediterranean Biogeography}

Even though it remains difficult to pinpoint a specific mechanism for protracted collision and delay in upper plate deformation, our results highlight a direct - and unexpectedgeodynamic and paleogeographic control on the regional fauna. Backarc rifting in the middle Cretaceous isolated the Pontides from Eurasia (Akdoğan et al., 2019; Okay \& Nikishin, 2015), setting the stage for Paleogene endemism. In Cretaceous-Paleogene times, Anatolia was an island archipelago separated from large continental domains (i.e., Afro-Arabia, Europe and Asia) by strands of the Paleotethys and Neotethys oceans (Barrier \& Vrielynck, 2008; van Hinsbergen et al., 2020). Gradual Late Cretaceous to early Eocene convergence and collision favored colonization of the Pontides by Gondwanan and Laurasian mammalian clades via "island hopping" across the Neotethyan archipelago (Beard et al., 2020; Jones et al., 2018; Kappelman et al., 1996; Licht et al., 2017; Métais et al., 2017; Sen, 2013). The TVZ-SKZ collision assembled a larger subaerial continental landmass that further promoted in situ diversification of endemic taxa (Maas et al., 2001; Métais et al., 2018). Endemism persisted until at least the Lutetian (44$43 \mathrm{Ma}$; Licht et al., 2017), a time when much of Anatolia was near sea level (e.g., Licht et al., 2017; Lygina et al., 2016; MTA, 2002; Ocakoğlu et al., 2012; Özcan et al., 2019; Racey, 2001). Therefore, the protracted nature of the collision, especially with respect to evolving plate coupling, is pertinent to the timing and magnitude of crustal thickening and topographic development and might explain the persistence of seaways and faunal isolation until late in the collision timeline (Beard et al., 2020b; Jones et al., 2018; Licht et al., 2017; Métais et al., 2018; Sen, 2013). In this way, the protracted nature of IAES collision is relevant to the evolution of emergent landmasses and exemplifies a direct influence of geodynamics and tectonics on biogeography. 
manuscript submitted to Geochemistry, Geophysics, Geosystems

\section{Conclusion}

The uninterrupted sedimentary record of the forearc-to-foreland Central Sakarya Basin records a complete history of progressive intercontinental collision that can serve as an example for Tethyan collisions. This sedimentary basin highlights how geodynamic mechanisms involving changing plate coupling can reconcile and synthesize collision proxies with seeming 15-40 Myr discrepancies into a holistic model for protracted collisions. During Cenomanian to early Campanian times (94-76 Ma), the CSB forearc basin received detritus from the Pontide volcanic belt, likely located at the southern margin of the CSB. Phase 2 started at $76 \mathrm{Ma}$ with the appearance of recycled basement-aged zircons in CSB strata, northward prograding deltas (Ocakoğlu et al., 2018) and increased in mafic input (Açıkalın et al., 2016), which record İAES uplift and exhumation attributed to the onset of TVZ-SKZ continental collision. Phase 3 began at $54 \mathrm{Ma}$ and is associated with to the onset of thick-skinned deformation, foreland basin partitioning, and regional syn-collisional magmatism.

The shift in deformation regime $20 \mathrm{Myr}$ after initial intercontinental collision emphasizes the protracted nature of the collision. The duration of IAES suturing may be explained by aspects of three multi-phase collision models that implicate a change in plate coupling: slab breakoff, relict basin closure, and underthrusting of progressively thicker lithosphere. Given the debated chronology of relict basin closure and the setting of Eocene magmatism, the underthrusting of progressively thicker lower plate passive margin lithosphere is the best and simplest explanation for protracted collision in western Anatolia.

\section{Acknowledgments}

We thank Cassandra Brigham, Alison Duvall, Katharine Huntington, Begüm Kurtoğlu, Spencer Mattingly, Çelik Ocakoğlu, Ben Paulson, Aurora Rosenberger, Theresa Schwartz, Tamas Ugrai, and Melissa Wood for prolific discussions and for field and lab assistance. We thank Editor Peter van der Beek and Aral Okay and two anonymous reviewers for providing constructive and thoughtful reviews. This work was supported by NSF EAR-1543684 and Eskişehir Osmangazi University Fund 200715024. Datasets for this research are included in the supplementary information files and archived in a data repository (http://dx.doi.org/10.17632/hz5dxh9vrn.1). 
manuscript submitted to Geochemistry, Geophysics, Geosystems

562

563

564

565

566

567

568

569

570

571

572

573

574

575

576

577

578

579

580

581

582

583

584

585

586

587

588

589

590

591

592

593

594

595

596

597

598

599

600

601

602

603

\section{References}

Açıkalın, S., Ocakoğlu, F., Yılmaz, İ. Ö., Vonhof, H., Hakyemez, A., \& Smit, J. (2016). Stable isotopes and geochemistry of a Campanian-Maastrichtian pelagic succession, MudurnuGöynük Basin, NW Turkey: Implications for palaeoceanography, palaeoclimate and sealevel fluctuations. Palaeogeography, Palaeoclimatology, Palaeoecology, 441, 453-466. https://doi.org/10.1016/j.palaeo.2015.10.005

Akbayram, K., Okay, A. I., \& Satır, M. (2013). Early Cretaceous closure of the Intra-Pontide Ocean in western Pontides (northwestern Turkey). Journal of Geodynamics, 65, 38-55. https://doi.org/10.1016/j.jog.2012.05.003

Akbayram, K., Sengor, A. M. C., \& Ozcan, E. (2016). The evolution of the intra-Pontide suture; implications of the discovery of late Cretaceous-early Tertiary melanges. Geological Society of America, Special Paper 525. https://doi.org/10.1130/2016.2525(18)

Akdoğan, R., Okay, A. I., Sunal, G., Tari, G., Meinhold, G., \& Kylander-Clark, A. R. C. (2017). Provenance of a large Lower Cretaceous turbidite submarine fan complex on the active Laurasian margin: Central Pontides, northern Turkey. Journal of Asian Earth Sciences, 134, 309-329. https://doi.org/10.1016/j.jseaes.2016.11.028

Akdoğan, R., Okay, A. I., \& Dunk1, I. (2019). Striking Variation in the Provenance of the Lower and Upper Cretaceous Turbidites in the Central Pontides (Northern Turkey) Related to the Opening of the Black Sea. Tectonics, 38(3), 1050-1069. https://doi.org/10.1029/2018TC005119

Aksay, A., Pehlivan, Ş., Gedik, I., Bilginer, E., Duru, M., Akbaş, B., \& Altun, I. (2002). Geologic map of Turkey (Zonguldak, Scale 1:500,000). Ankara, Turkey: Maden Tetkik ve Arma Genel Müdürlüğü.

Altiner, D., Kocyigit, A., Farinacci, A., Nicosia, U., \& Conti, M. A. (1991). Jurrasic-Lower Cretaceous stratigraphy and paleogeographic evolution of the southern part of NorthWestern Anatolia (Turkey). Geologica Romana, 27, 13-80.

Altunkaynak, Ş. (2007). Collision-Driven Slab Breakoff Magmatism in Northwestern Anatolia, Turkey. The Journal of Geology, 115(1), 63-82. https://doi.org/10.1086/509268

Altunkaynak, Ş., Sunal, G., Aldanmaz, E., Genç, C. Ş., Dilek, Y., Furnes, H., et al. (2012). Eocene Granitic Magmatism in NW Anatolia (Turkey) revisited: New implications from comparative zircon SHRIMP U-Pb and 40Ar-39Ar geochronology and isotope geochemistry on magma genesis and emplacement. Lithos, 155, 289-309. https://doi.org/10.1016/j.lithos.2012.09.008

Alvarez, W. (2010). Protracted continental collisions argue for continental plates driven by basal traction. Earth and Planetary Science Letters, 296(3), 434-442. https://doi.org/10.1016/j.epsl.2010.05.030

Avdeev, B., \& Niemi, N. A. (2011). Rapid Pliocene exhumation of the central Greater Caucasus constrained by low-temperature thermochronometry. Tectonics, 30(2). https://doi.org/10.1029/2010TC002808

Ballato, P., Uba, C. E., Landgraf, A., Strecker, M. R., Sudo, M., Stockli, D. F., et al. (2011). Arabia-Eurasia continental collision: Insights from late Tertiary foreland-basin evolution in the Alborz Mountains, northern Iran. GSA Bulletin, 123(1-2), 106-131. https://doi.org/10.1130/B30091.1 
Ballato, P., Parra, M., Schildgen, T. F., Dunkl, I., Yıldırım, C., Özsayın, E., et al. (2018). Multiple Exhumation Phases in the Central Pontides (N Turkey): New Temporal Constraints on Major Geodynamic Changes Associated With the Closure of the NeoTethys Ocean. Tectonics, 37(6), 1831-1857. https://doi.org/10.1029/2017TC004808

Barrier, E., \& Vrielynck, B. (2008). Palaeotectonic Maps of the Middle East. Paris.

Baş, H. (1986). Tertiary geology of the Domaniç-Tavsanli-Kütahya-Gediz Region. Jeoloji Mühendisliği, 27(11), 11-18.

Beard, K. C., Métais, G., Ocakoğlu, F., \& Licht, A. (2020a). An omomyid primate from the Pontide microcontinent of north-central Anatolia: Implications for sweepstakes dispersal of terrestrial mammals during the Eocene. Geobios. https://doi.org/10.1016/j.geobios.2020.06.008

Beard, K. C., Métais, G., Ocakoğlu, F., \& Licht, A. (2020b). An omomyid primate from the Pontide microcontinent of north-central Anatolia: Implications for sweepstakes dispersal of terrestrial mammals during the Eocene. Geobios. https://doi.org/10.1016/j.geobios.2020.06.008

Beaumont, C., Ellis, S., Hamilton, J., \& Fullsack, P. (1996). Mechanical model for subductioncollision tectonics of Alpine-type compressional orogens. Geology, 24(8), 675-678. https://doi.org/10.1130/0091-7613(1996)024<0675:MMFSCT>2.3.CO;2

Becker, T. W., \& Faccenna, C. (2011). Mantle conveyor beneath the Tethyan collisional belt. Earth and Planetary Science Letters, 310(3), 453-461. https://doi.org/10.1016/j.epsl.2011.08.021

von Blanckenburg, F., \& Davies, J. H. (1995). Slab breakoff: A model for syncollisional magmatism and tectonics in the Alps. Tectonics, 14(1), 120-131. https://doi.org/10.1029/94TC02051

Campbell, C. F. (2017). Tectonic Evolution of the Izmir-Ankara Suture Zone in Northwest Turkey using Zircon U-Pb Geochronology and Zircon Lu-Hf Isotopic Tracers (M.S.). University of Kansas, United States -- Kansas. Retrieved from http://search.proquest.com/pqdtglobal/docview/2019635859/abstract/4D50BF261D20484 $4 \mathrm{PQ} / 1$

Cowgill, E., Forte, A. M., Niemi, N., Avdeev, B., Tye, A., Trexler, C., et al. (2016). Relict basin closure and crustal shortening budgets during continental collision: An example from Caucasus sediment provenance. Tectonics, 35(12), 2918-2947. https://doi.org/10.1002/2016TC004295

Darin, M. H., Umhoefer, P. J., \& Thomson, S. N. (2018). Rapid Late Eocene Exhumation of the Sivas Basin (Central Anatolia) Driven by Initial Arabia-Eurasia Collision. Tectonics. https://doi.org/10.1029/2017TC004954

Davies, J. H., \& von Blanckenburg, F. (1995). Slab breakoff: A model of lithosphere detachment and its test in the magmatism and deformation of collisional orogens. Earth and Planetary Science Letters, 129(1), 85-102. https://doi.org/10.1016/0012-821X(94)00237$\mathrm{S}$

DeCelles, P. G., Kapp, P., Quade, J., \& Gehrels, G. E. (2011). Oligocene-Miocene Kailas basin, southwestern Tibet: Record of postcollisional upper-plate extension in the Indus-Yarlung suture zone. GSA Bulletin, 123(7-8), 1337-1362. https://doi.org/10.1130/B30258.1

Di Rosa, M., Farina, F., Marroni, M., Pandolfi, L., Göncüoğlu, M. C., Ellero, A., \& Ottria, G. (2019). U-Pb zircon geochronology of intrusive rocks from an exotic block in the Late Cretaceous - Paleocene Tarakl1 Flysch (northern Turkey): Constraints on the tectonics of 
manuscript submitted to Geochemistry, Geophysics, Geosystems

the Intrapontide suture zone. Journal of Asian Earth Sciences, 171, 277-288. https://doi.org/10.1016/j.jseaes.2018.11.017

Dickinson, W. R. (1985). Interpreting provenance relations from detrital modes of sandstones. In G. G. Zuffa (Ed.), Provenance of Arenites (pp. 333-361). Dordrecht: Reidel.

Dickinson, W. R., \& Suczek, C. A. (1979). Plate Tectonics and Sandstone Compositions. AAPG Bulletin, 63(12), 2164-2182.

Dilek, Y., \& Altunkaynak, Ş. (2009). Geochemical and temporal evolution of Cenozoic magmatism in western Turkey: mantle response to collision, slab break-off, and lithospheric tearing in an orogenic belt. Geological Society, London, Special Publications, 311(1), 213-233. https://doi.org/10.1144/SP311.8

Dilek, Y., Thy, P., Hacker, B., \& Grundvig, S. (1999). Structure and petrology of Tauride ophiolites and mafic dike intrusions (Turkey): Implications for the Neotethyan ocean. Geological Society of America Bulletin, 25.

Ding, L., Kapp, P., \& Wan, X. (2005). Paleocene-Eocene record of ophiolite obduction and initial India-Asia collision, south central Tibet. Tectonics, 24(3). https://doi.org/10.1029/2004TC001729

Ding, L., Qasim, M., Jadoon, I. A. K., Khan, M. A., Xu, Q., Cai, F., et al. (2016). The India-Asia collision in north Pakistan: Insight from the $\mathrm{U}-\mathrm{Pb}$ detrital zircon provenance of Cenozoic foreland basin. Earth and Planetary Science Letters, 455, 49-61. https://doi.org/10.1016/j.eps1.2016.09.003

Duru, M., \& Aksay, A. (2002). Geological map of the Adapazari quadrangle (Sheet H 24, Scale 1:100,000). Ankara, Turkey: Maden Tetkik ve Arma Genel Müdürlüğ̈̈.

Ersoy, E. Y., Palmer, M. R., Genç, Ş. C., Prelević, D., Akal, C., \& Uysal, İ. (2017). Chemoprobe into the mantle origin of the NW Anatolia Eocene to Miocene volcanic rocks: Implications for the role of, crustal accretion, subduction, slab roll-back and slab breakoff processes in genesis of post-collisional magmatism. Lithos, 288-289, 55-71. https://doi.org/10.1016/j.lithos.2017.07.006

Ersoy, E. Y., Akal, C., Genç, Ş. C., Candan, O., Palmer, M. R., Prelević, D., et al. (2017). U-Pb zircon geochronology of the Paleogene - Neogene volcanism in the NW Anatolia: Its implications for the Late Mesozoic-Cenozoic geodynamic evolution of the Aegean. Tectonophysics, 717, 284-301. https://doi.org/10.1016/j.tecto.2017.08.016

Garzanti, E., Radeff, G., \& Malusà, M. G. (2018). Slab breakoff: A critical appraisal of a geological theory as applied in space and time. Earth-Science Reviews, 177, 303-319. https://doi.org/10.1016/j.earscirev.2017.11.012

Gedik, I., \& Aksay, A. (2002). Geological map of the Adapazari quadrangle (Sheet H 25, Scale 1:100,000). Ankara, Turkey: Maden Tetkik ve Arma Genel Müdürlüğü.

Gehrels, G. (2012). Detrital Zircon U-Pb Geochronology: Current Methods and New Opportunities. In C. Busby \& A. Azor (Eds.), Tectonics of Sedimentary Basins (pp. 4562). Chichester, UK: John Wiley \& Sons, Ltd. https://doi.org/10.1002/9781444347166.ch2

Gehrels, G. (2014). Detrital Zircon U-Pb Geochronology Applied to Tectonics. Annual Review of Earth and Planetary Sciences, 42(1), 127-149. https://doi.org/10.1146/annurev-earth050212-124012

Genç, Ş. C., \& Tüysüz, O. (2010). Tectonic setting of the Jurassic bimodal magmatism in the Sakarya Zone (Central and Western Pontides), Northern Turkey: A geochemical and isotopic approach. Lithos, 118(1), 95-111. https://doi.org/10.1016/j.lithos.2010.03.017 
Gögüü, O. H., Pysklywec, R. N., \& Faccenna, C. (2016). Postcollisional lithospheric evolution of the Southeast Carpathians: Comparison of geodynamical models and observations. Tectonics, 35(5), 1205-1224. https://doi.org/10.1002/2015TC004096

Göncüoğlu, M. C., Turhan, N., Şentürk, K., Özcan, A., Uysal, Ş., \& Yaliniz, M. K. (2000). A Geotraverse Across Northwestern Turkey: Tectonic Units of the Central Sakarya Region and their Tectonic Evolution. Geological Society, London, Special Publications, 173(1), 139-161. https://doi.org/10.1144/GSL.SP.2000.173.01.06

Göncüoğlu, M. C., Sayit, K., \& Tekin, U. K. (2010). Oceanization of the northern Neotethys: Geochemical evidence from ophiolitic melange basalts within the İzmir-Ankara suture belt, NW Turkey. Lithos, 116(1), 175-187. https://doi.org/10.1016/j.lithos.2010.01.007

Göncüoğlu, M. C., Marroni, M., Pandolfi, L., Ellero, A., Ottria, G., Catanzariti, R., et al. (2014). The Arkot Dağ Mélange in Araç area, central Turkey: Evidence of its origin within the geodynamic evolution of the Intra-Pontide suture zone. Journal of Asian Earth Sciences, 85, 117-139. https://doi.org/10.1016/j.jseaes.2014.01.013

Graham, D. J., \& Midgley, N. G. (2000). Graphical representation of particle shape using triangular diagrams: an Excel spreadsheet method. Earth Surface Processes and Landforms, 25(13), 1473-1477. https://doi.org/10.1002/10969837(200012)25:13<1473::AID-ESP158>3.0.CO;2-C

Harris, N. B. W., Kelley, S., \& Okay, A. I. (1994). Post-collisional magmatism and tectonics in northwest Anatolia. Contributions to Mineralogy and Petrology, 117(3), 241-252.

Helvac1, C., Yücel Öztürk, Y., Satır, M., \& Shang, C. K. (2014). U-Pb zircon and K-Ar geochronology reveal the emplacement and cooling history of the Late Cretaceous Beypazarı granitoid, central Anatolia, Turkey. International Geology Review, 56(9), 1138-1155. https://doi.org/10.1080/00206814.2014.921795

van Hinsbergen, D. J. J., Kaymakci, N., Spakman, W., \& Torsvik, T. H. (2010). Reconciling the geological history of western Turkey with plate circuits and mantle tomography. Earth and Planetary Science Letters, 297(3-4), 674-686. https://doi.org/10.1016/j.epsl.2010.07.024

van Hinsbergen, D. J. J., Kapp, P., Dupont-Nivet, G., Lippert, P. C., DeCelles, P. G., \& Torsvik, T. H. (2011). Restoration of Cenozoic deformation in Asia and the size of Greater India. Tectonics, 30(5). https://doi.org/10.1029/2011TC002908

van Hinsbergen, D. J. J., Lippert, P. C., Dupont-Nivet, G., McQuarrie, N., Doubrovine, P. V., Spakman, W., \& Torsvik, T. H. (2012). Greater India Basin hypothesis and a two-stage Cenozoic collision between India and Asia. Proceedings of the National Academy of Sciences, 109(20), 7659-7664. https://doi.org/10.1073/pnas.1117262109

van Hinsbergen, D. J. J., Torsvik, T. H., Schmid, S. M., Maţenco, L. C., Maffione, M., Vissers, R. L. M., et al. (2020). Orogenic architecture of the Mediterranean region and kinematic reconstruction of its tectonic evolution since the Triassic. Gondwana Research, 81, 79229. https://doi.org/10.1016/j.gr.2019.07.009

Hu, X., Garzanti, E., Wang, J., Huang, W., An, W., \& Webb, A. (2016). The timing of IndiaAsia collision onset - Facts, theories, controversies. Earth-Science Reviews, 160, 264299. https://doi.org/10.1016/j.earscirev.2016.07.014

Jagoutz, O., Royden, L., Holt, A. F., \& Becker, T. W. (2015). Anomalously fast convergence of India and Eurasia caused by double subduction. Nature Geoscience, 8(6), 475-478. https://doi.org/10.1038/ngeo2418 
Jagoutz, O., Macdonald, F. A., \& Royden, L. (2016). Low-latitude arc-continent collision as a driver for global cooling. Proceedings of the National Academy of Sciences, 113(18), 4935-4940. https://doi.org/10.1073/pnas.1523667113

Jones, M. F., Coster, P. M. C., Licht, A., Métais, G., Ocakoğlu, F., Taylor, M. H., \& Beard, K. C. (2018). A stem bat (Chiroptera: Palaeochiropterygidae) from the late middle Eocene of northern Anatolia: implications for the dispersal and palaeobiology of early bats. Palaeobiodiversity and Palaeoenvironments. https://doi.org/10.1007/s12549-018-0338-z

Kapp, P., \& DeCelles, P. G. (2019). Mesozoic-Cenozoic geological evolution of the HimalayanTibetan orogen and working tectonic hypotheses. American Journal of Science, 319(3), 159-254. https://doi.org/10.2475/03.2019.01

Kappelman, J., Maas, M. C., Sen, S., Alpagut, B., Fortelius, M., \& Lunkka, J.-P. (1996). A new early Tertiary mammalian fauna from Turkey and its paleobiogeographic significance. Journal of Vertebrate Paleontology, 16(3), 592-595. https://doi.org/10.1080/02724634.1996.10011345

Kasapoğlu, B., Ersoy, Y. E., Uysal, İ., Palmer, M. R., Zack, T., Koralay, E. O., \& Karlsson, A. (2016). The petrology of Paleogene volcanism in the Central Sakarya, Nallihan Region: Implications for the initiation and evolution of post-collisional, slab break-off-related magmatic activity. Lithos, 246-247, 81-98. https://doi.org/10.1016/j.lithos.2015.12.024

Kaymakci, N., Özçelik, Y., White, S. H., \& Van Dijk, P. M. (2009). Tectono-stratigraphy of the Çankırı Basin: Late Cretaceous to early Miocene evolution of the Neotethyan Suture Zone in Turkey. Geological Society, London, Special Publications, 311(1), 67-106. https://doi.org/10.1144/SP311.3

Keskin, M., \& Tüysüz, O. (2018). Stratigraphy, petrogenesis and geodynamic setting of Late Cretaceous volcanism on the SW margin of the Black Sea, Turkey. Geological Society, London, Special Publications, 464(1), 95-130. https://doi.org/10.1144/SP464.5

Koshnaw, R. I., Stockli, D. F., \& Schlunegger, F. (2019). Timing of the Arabia-Eurasia continental collision-Evidence from detrital zircon U-Pb geochronology of the Red Bed Series strata of the northwest Zagros hinterland, Kurdistan region of Iraq. Geology, 47(1), 47-50. https://doi.org/10.1130/G45499.1

Leary, R., Orme, D. A., Laskowski, A. K., DeCelles, P. G., Kapp, P., Carrapa, B., \& Dettinger, M. (2016). Along-strike diachroneity in deposition of the Kailas Formation in central southern Tibet: Implications for Indian slab dynamics. Geosphere, 12(4), 1198-1223. https://doi.org/10.1130/GES01325.1

Lefebvre, C., Meijers, M. J. M., Kaymakci, N., Peynircioğlu, A., Langereis, C. G., \& van Hinsbergen, D. J. J. (2013). Reconstructing the geometry of central Anatolia during the late Cretaceous: Large-scale Cenozoic rotations and deformation between the Pontides and Taurides. Earth and Planetary Science Letters, 366, 83-98. https://doi.org/10.1016/j.eps1.2013.01.003

Licht, A., Coster, P., Ocakoğlu, F., Campbell, C., Métais, G., Mulch, A., et al. (2017). Tectonostratigraphy of the Orhaniye Basin, Turkey: Implications for collision chronology and Paleogene biogeography of central Anatolia. Journal of Asian Earth Sciences, 143, 4558. https://doi.org/10.1016/j.jseaes.2017.03.033

Licht, A., Dupont-Nivet, G., Win, Z., Swe, H. H., Kaythi, M., Roperch, P., et al. (2018). Paleogene evolution of the Burmese forearc basin and implications for the history of India-Asia convergence. GSA Bulletin, 5-6, 730-748. https://doi.org/10.1130/B35002.1 
Lygina, E. A., Fokin, P. A., Kopaevich, L. F., Nikishin, A. M., \& Yakovishina, E. V. (2016). Nummulitic facies of the Crimean-Caucasian Region. Turkish Journal of Earth Sciences, 25, 163-178. https://doi.org/10.3906/yer-1404-20

Maas, M. C., Thewissen, J. G. M., Sen, S., Kazanci, N., \& Kappelman, J. (2001). Enigmatic new ungulates from the Early Middle Eocene of central Anatolia, Turkey. Journal of Vertebrate Paleontology, 21(3), 578-590. https://doi.org/10.1671/02724634(2001)021[0578:ENUFTE]2.0.CO;2

Martin, C. R., Jagoutz, O., Upadhyay, R., Royden, L. H., Eddy, M. P., Bailey, E., et al. (2020). Paleocene latitude of the Kohistan-Ladakh arc indicates multistage India-Eurasia collision. Proceedings of the National Academy of Sciences. https://doi.org/10.1073/pnas.2009039117

McLean, N. M., Bowring, J. F., \& Gehrels, G. (2016). Algorithms and software for U-Pb geochronology by LA-ICPMS. Geochemistry, Geophysics, Geosystems, 17(7), 24802496. https://doi.org/10.1002/2015GC006097

McQuarrie, N., \& van Hinsbergen, D. J. J. (2013). Retrodeforming the Arabia-Eurasia collision zone: Age of collision versus magnitude of continental subduction. Geology, 41(3), 315318. https://doi.org/10.1130/G33591.1

McQuarrie, N., Stock, J. M., Verdel, C., \& Wernicke, B. P. (2003). Cenozoic evolution of Neotethys and implications for the causes of plate motions. Geophysical Research Letters, 30(20). https://doi.org/10.1029/2003GL017992

Meijers, M. J. M., Kaymakci, N., Hinsbergen, D. J. J. van, Langereis, C. G., Stephenson, R. A., \& Hippolyte, J.-C. (2010). Late Cretaceous to Paleocene oroclinal bending in the central Pontides (Turkey). Tectonics, 29(4). https://doi.org/10.1029/2009TC002620

Métais, G., Beard, K., Erdal, O., \& Erturaç, K. (2017). Tarsal morphology of the pleuraspidotheriid mammal Hilalia from the middle Eocene of Turkey. Acta Palaeontologica Polonica, 62. https://doi.org/10.4202/app.00314.2016

Métais, G., Coster, P. M., Kappelman, J. R., Licht, A., Ocakoglu, F., Taylor, M. H., \& Beard, K. C. (2018). Eocene metatherians from Anatolia illuminate the assembly of an island fauna during Deep Time. PLoS ONE, 13(11), e0206181.

MTA. (2002). Geological map of Turkey, scale 1:500,000. Mineral Research and Exploration Institute of Turkey.

Mueller, M. A., Licht, A., Campbell, C., Ocakoğlu, F., Taylor, M. H., Burch, L., et al. (2019). Collision Chronology Along the İzmir-Ankara-Erzincan Suture Zone: Insights From the Sarıcakaya Basin, Western Anatolia. Tectonics, 38(10), 3652-3674. https://doi.org/10.1029/2019TC005683

Najman, Y., Appel, E., Boudagher-Fadel, M., Bown, P., Carter, A., Garzanti, E., et al. (2010). Timing of India-Asia collision: Geological, biostratigraphic, and palaeomagnetic constraints. Journal of Geophysical Research: Solid Earth, 115(B12). https://doi.org/10.1029/2010JB007673

Niu, Y. (2017). Slab breakoff: a causal mechanism or pure convenience? Science Bulletin, 62(7), 456-461. https://doi.org/10.1016/j.scib.2017.03.015

Ocakoğlu, F., Yılmaz, İ. Ö., Demircan, H., Altıner, S. Ö., Hakyemez, A., İslamoğlu, Y., et al. (2007). Orta Sakarya Bölgesi Geç Kretase-Paleojen Çökellerinin Sekans Stratigrafisi. The Scientific and Technological Research Council of Turkey (TUBITAK, Project no: 104Y153), Final Report, 476. 
Ocakoğlu, F., Açıkalın, S., Yılmaz, I. ö., Şafak, ü., \& Gökçeoğlu, C. (2012). Evidence of orbital forcing in lake-level fluctuations in the Middle Eocene oil shale-bearing lacustrine successions in the Mudurnu-Göynük Basin, NW Anatolia (Turkey). Journal of Asian Earth Sciences, 56, 54-71. https://doi.org/10.1016/j.jseaes.2012.04.021

Ocakoğlu, F., Hakyemez, A., Açıkalın, S., Özkan Altıner, S., Büyükmeriç, Y., Licht, A., et al. (2018). Chronology of subduction and collision along the İzmir-Ankara suture in Western Anatolia: records from the Central Sakarya Basin. International Geology Review, 1-26. https://doi.org/10.1080/00206814.2018.1507009

Okay, A. (2011). TAVSANLI ZONE: THE NORTHERN SUBDUCTED MARGIN OF THE ANATOLIDE-TAURIDE BLOCK. Mineral Res. Expl. Bull., 142, 191-221.

Okay, A., \& Satir, M. (2006). Geochronology of Eocene plutonism and metamorphism in northwest. Geodinamica Acta, 19(5), 251-266. https://doi.org/10.3166/ga.19.251-266

Okay, A., Satir, M., maluski, H., SIYAKO, M., Monie, P., Metzger, R., \& Akyüz, S. (1996). Paleo- and Neo-Tethyan events in northwestern Turkey: Geologic and geochronologic constraints. Cambridge University Press, 420-441.

Okay, A., Harris, N. B. W., \& Kelley, S. P. (1998). Exhumation of blueschists along a Tethyan suture in northwest Turkey. Tectonophysics, 285(3-4), 275-299. https://doi.org/10.1016/S0040-1951(97)00275-8

Okay, A. I., \& Göncüoglu, M. C. (2004). The Karakaya Complex: A Review of Data and Concepts. Turkish Journal of Earth Sciences, 13(2), 77-95.

Okay, A. I., \& Nikishin, A. M. (2015). Tectonic evolution of the southern margin of Laurasia in the Black Sea region. International Geology Review, 57(5-8), 1051-1076. https://doi.org/10.1080/00206814.2015.1010609

Okay, A. I., \& Tüysüz, O. (1999). Tethyan sutures of northern Turkey. Geological Society, London, Special Publications, 156(1), 475-515. https://doi.org/10.1144/GSL.SP.1999.156.01.22

Okay, A. I., \& Whitney, D. L. (2010). Blueschists, Eclogites, Ophiolites and Suture Zones in Northwest Turkey: A Review and a Field Excursion Guide. Ofioliti, 35(2), 131-172.

Okay, A. I., Şengör, A. M. C., \& Görür, N. (1994). Kinematic history of the opening of the Black Sea and its effect on the surrounding regions. Geology, 22(3), 267-270. https://doi.org/10.1130/0091-7613(1994)022<0267:KHOTOO>2.3.CO;2

Okay, A. I., Tansel, I., \& TüYsüZ, O. (2001). Obduction, subduction and collision as reflected in the Upper Cretaceous-Lower Eocene sedimentary record of western Turkey. Geological Magazine, 138(02). https://doi.org/10.1017/S0016756801005088

Okay, A. I., Zattin, M., \& Cavazza, W. (2010). Apatite fission-track data for the Miocene Arabia-Eurasia collision. Geology, 38(1), 35-38. https://doi.org/10.1130/G30234.1

Okay, A. I., Sunal, G., Sherlock, S., Altiner, D., Tüysüz, O., Kylander-Clark, A. R. C., \& Aygül, M. (2013). Early Cretaceous sedimentation and orogeny on the active margin of Eurasia: Southern Central Pontides, Turkey. Tectonics, 32(5), 1247-1271. https://doi.org/10.1002/tect.20077

Okay, A. I., Altıner, D., \& Kylander-Clark, A. R. C. (2019). Major Late Cretaceous Mass Flows in Central Turkey Recording the Disruption of the Mesozoic Continental Margin. Tectonics, 38(3), 960-989. https://doi.org/10.1029/2018TC005076

Okay, A. I., Sunal, G., Sherlock, S., Kylander-Clark, A. R. C., \& Özcan, E. (2020). İzmir-Ankara Suture as a Triassic to Cretaceous Plate Boundary-Data From Central Anatolia. Tectonics, 39(5), e2019TC005849. https://doi.org/10.1029/2019TC005849 
Özcan, E., Özcan, Z., Okay, A. I., Akbayram, K., \& Hakyemez, A. (2019). The Ypresian to Lutetian marine record in NW Turkey: a revised biostratigraphy and chronostratigraphy and implications for Eocene paleogeography. Turkish Journal of Earth Sciences, 28, 27.

Özcan, Z., Okay, A. I., Özcan, E., Hakyemez, A., \& Özkan-Altiner, S. (2012). Late CretaceousEocene Geological Evolution of the Pontides Based on New Stratigraphic and Palaeontologic Data Between the Black Sea Coast and Bursa (NW Turkey). Turkish Journal of Earth Sciences, 21, 933-960. https://doi.org/10.3906/yer-1102-8

Özgen-Erdem, N., Akyazı, M., \& Karabaşoğlu, A. (2007). Biostratigraphic interpretation and systematics of Alveolina assemblages from the Ilerdian-Cuisian limestones of Southern Eskişehir, Central Turkey. Journal of Asian Earth Sciences, 29(5), 911-927. https://doi.org/10.1016/j.jseaes.2006.05.010

Paterson, S. R., \& Ducea, M. N. (2015). Arc Magmatic Tempos: Gathering the Evidence. Elements, 11(2), 91-98. https://doi.org/10.2113/gselements.11.2.91

Paton, C., Hellstrom, J., Paul, B., Woodhead, J., \& Hergt, J. (2011). Iolite: Freeware for the visualisation and processing of mass spectrometric data. Journal of Analytical Atomic Spectrometry, 26(12), 2508. https://doi.org/10.1039/c1ja10172b

Plunder, A., Agard, P., Chopin, C., \& Okay, A. (2013). Tectono-metamorphic evolution of the Tavşanli zone, Western Anatolia: implications for mechanical coupling during subduction/obduction processes (Vol. 15, pp. EGU2013-8404). Presented at the EGU General Assembly Conference Abstracts. Retrieved from http://adsabs.harvard.edu/abs/2013EGUGA..15.8404P

Plunder, A., Agard, P., Chopin, C., Pourteau, A., \& Okay, A. I. (2015). Accretion, underplating and exhumation along a subduction interface: From subduction initiation to continental subduction (Tavşanlı zone, W. Turkey). Lithos, 226, 233-254. https://doi.org/10.1016/j.lithos.2015.01.007

Pourteau, A., Sudo, M., Candan, O., Lanari, P., Vidal, O., \& Oberhänsli, R. (2013). Neotethys closure history of Anatolia: insights from ${ }^{40} \mathrm{Ar}-{ }^{39} \mathrm{Ar}$ geochronology and $P-T$ estimation in high-pressure metasedimentary rocks. Journal of Metamorphic Geology, 31(6), 585606. https://doi.org/10.1111/jmg.12034

Pourteau, A., Oberhänsli, R., Candan, O., Barrier, E., \& Vrielynck, B. (2016). Neotethyan closure history of western Anatolia: a geodynamic discussion. International Journal of Earth Sciences, 105(1), 203-224. https://doi.org/10.1007/s00531-015-1226-7

Pourteau, A., Scherer, E. E., Schorn, S., Bast, R., Schmidt, A., \& Ebert, L. (2019). Thermal evolution of an ancient subduction interface revealed by Lu-Hf garnet geochronology, Halilbağ1 Complex (Anatolia). Geoscience Frontiers, 10(1), 127-148. https://doi.org/10.1016/j.gsf.2018.03.004

Racey, A. (2001). A review of Eocene nummulite accumulations: Structure, formation and reservoir potential. Journal of Petroleum Geology, 24(1), 79-100. https://doi.org/10.1111/j.1747-5457.2001.tb00662.x

Robertson, A. H. F., \& Ustaömer, T. (2004). Tectonic evolution of the Intra-Pontide suture zone in the Armutlu Peninsula, NW Turkey. Tectonophysics, 381(1-4), 175-209. https://doi.org/10.1016/j.tecto.2002.06.002

Robertson, A. H. F., Parlak, O., \& Ustaömer, T. (2009). Melange genesis and ophiolite emplacement related to subduction of the northern margin of the Tauride-Anatolide continent, central and western Turkey. Geological Society, London, Special Publications, 311(1), 9-66. https://doi.org/10.1144/SP311.2 
Şafak, Ü., Ocakoğlu, F., \& Açıkalın, S. (2015). Ostracoda assemblage and the environmental characteristics of the Eocene Succession of the Central Sakarya Region. Micropaleontology, 61(1/2), 49-68.

Şahin, M., Yaltırak, C., \& Karacık, Z. (2019). A case study of compression to escape tectonic transition: Tectonic evolution of the Nallıhan Wedge and comparison with the Tercan Wedge (Eastern Mediterranean, Turkey). Journal of Asian Earth Sciences, 174, 311-331. https://doi.org/10.1016/j.jseaes.2018.12.016

Sarıfakığlu, E., Özen, H., \& Winchester, J. A. (2009). Whole Rock and Mineral Chemistry of Ultramafic-mafic Cumulates from the Orhaneli (Bursa) Ophiolite, NW Anatolia. Turkish Journal of Earth Sciences, 18, 55-83. https://doi.org/10.3906/yer-0806-8

Sarıfakığlu, E., Dilek, Y., \& Sevin, M. (2017). New synthesis of the Izmir-Ankara-Erzincan suture zone and the Ankara mélange in northern Anatolia based on new geochemical and geochronological constraints. In R. Sorkhabi (Ed.), Tectonic Evolution, Collision, and Seismicity of Southwest Asia: In Honor of Manuel Berberian's Forty-Five Years of Research Contributions (Vol. 525, pp. 1-63). Retrieved from https://doi.org/10.1130/2017.2525(19)

Schleiffarth, W. K., Darin, M. H., Reid, M. R., \& Umhoefer, P. J. (2018). Dynamics of episodic Late Cretaceous-Cenozoic magmatism across Central to Eastern Anatolia: New insights from an extensive geochronology compilation. Geosphere, 14(5), 1990-2008. https://doi.org/10.1130/GES01647.1

Seaton, N. C. A., Whitney, D. L., Teyssier, C., Toraman, E., \& Heizler, M. T. (2009). Recrystallization of high-pressure marble (Sivrihisar, Turkey). Tectonophysics, 479(3), 241-253. https://doi.org/10.1016/j.tecto.2009.08.015

Sen, S. (2013). Dispersal of African mammals in Eurasia during the Cenozoic: Ways and whys. Geobios, 46(1-2), 159-172. https://doi.org/10.1016/j.geobios.2012.10.012

Şengör, A. M. C., \& Yilmaz, Y. (1981). Tethyan evolution of turkey: a plate tectonic approach. Tectonophysics, 75, 181-241.

Sharman, G. R., Sharman, J. P., \& Sylvester, Z. (2018). detritalPy: A Python-based toolset for visualizing and analysing detrital geo-thermochronologic data. The Depositional Record, 4(2), 202-215. https://doi.org/10.1002/dep2.45

Shekut, S., \& Licht, A. (2020). Late Middle Miocene Emergence of the Olympic Peninsula Shown by Sedimentary Provenance. Lithosphere, 2020(1), 1-20. https://doi.org/10.2113/2020/7040598

Sherlock, S., Kelley, S., Inger, S., Harris, N., \& Okay, A. (1999). 40Ar-39Ar and Rb-Sr geochronology of high-pressure metamorphism and exhumation history of the Tavsanli Zone, NW Turkey. Contributions to Mineralogy and Petrology, 137(1-2), 46-58. https://doi.org/10.1007/PL00013777

Sinclair, H. D. (1997). Flysch to molasse transition in peripheral foreland basins: The role of the passive margin versus slab breakoff. Geology, 25(12), 1123-1126.

Soret, M., Larson, K. P., Cottle, J., \& Ali, A. (2021). How Himalayan collision stems from subduction. Geology. https://doi.org/10.1130/G48803.1

Speciale, P. A., Catlos, E. J., Y1ldı, G. O., Shin, T. A., \& Black, K. N. (2012). Zircon ages from the Beypazar1 granitoid pluton (north central Turkey): tectonic implications. Geodinamica Acta, 25(3-4), 162-182. https://doi.org/10.1080/09853111.2013.858955

Timur, E., \& Aksay, A. (2002). Geological map of the Adapazari quadrangle (Sheet H 26, Scale 1:100,000). Ankara, Turkey: Maden Tetkik ve Arma Genel Müdürlüğü. 
Turhan, N. (2002). Geologic map of Turkey (Ankara, Scale 1:500,000). Ankara, Turkey: Maden Tetkik ve Arma Genel Müdürlüğü.

Tye, A. R., Niemi, N. A., Safarov, R. T., Kadirov, F. A., \& Babayev, G. R. (2020). Sedimentary response to a collision orogeny recorded in detrital zircon provenance of Greater Caucasus foreland basin sediments. Basin Research, $n / a(\mathrm{n} / \mathrm{a})$. https://doi.org/10.1111/bre.12499

Ustaömer, P., Ustaömer, T., \& Robertson, Alastair. H. F. (2012). Ion Probe U-Pb Dating of the Central Sakarya Basement: A peri-Gondwana Terrane Intruded by Late Lower Carboniferous Subduction/Collision-related Granitic Rocks. Turkish Journal of Earth Sciences, 21(6), 905-932. https://doi.org/10.3906/yer-1103-1

Ustaömer, P. A., Ustaömer, T., Collins, A. S., \& Reischpeitsch, J. (2009). Lutetian arc-type magmatism along the southern Eurasian margin: New U-Pb LA-ICPMS and whole-rock geochemical data from Marmara Island, NW Turkey. Mineralogy and Petrology, 96(3), 177-196. https://doi.org/10.1007/s00710-009-0051-8

Ustaömer, T., Ustaömer, P., Robertson, A. H. F., \& Gerdes, A. (2016). Implications of U-Pb and $\mathrm{Lu}-\mathrm{Hf}$ isotopic analysis of detrital zircons for the depositional age, provenance and tectonic setting of the Permian-Triassic Palaeotethyan Karakaya Complex, NW Turkey. International Journal of Earth Sciences, 105(1), 7-38. https://doi.org/10.1007/s00531015-1225-8

Whitney, D. L., Teyssier, C., Toraman, E., Seaton, N. C. A., \& Fayon, A. K. (2011). Metamorphic and tectonic evolution of a structurally continuous blueschist-to-Barrovian terrane, Sivrihisar Massif, Turkey. Journal of Metamorphic Geology, 29(2), 193-212. https://doi.org/10.1111/j.1525-1314.2010.00915.x

Whitney, Donna L., \& Davis, P. B. (2006). Why is lawsonite eclogite so rare? Metamorphism and preservation of lawsonite eclogite, Sivrihisar, Turkey. Geology, 34(6), 473-476. https://doi.org/10.1130/G22259.1

Yildiz, A., Kibici, Y., Bağci, M., Dumlupunar, İ., Kocabaş, C., \& Aritan, A. E. (2015). Petrogenesis of the post-collisional Eocene volcanic rocks from the Central Sakarya Zone (Northwestern Anatolia, Turkey): Implications for source characteristics, magma evolution, and tectonic setting. Arabian Journal of Geosciences, 8(12), 11239-11260. https://doi.org/10.1007/s12517-015-1991-4

Yilmaz, I. O., Altiner, D., Tekin, U. K., Tuysuz, O., Ocakoglu, F., \& Acikalin, S. (2010). Cenomanian - Turonian Oceanic Anoxic Event (OAE2) in the Sakarya Zone, northwestern Turkey: Sedimentological, cyclostratigraphic, and geochemical records. Cretaceous Research, 31(2), 207-226. https://doi.org/10.1016/j.cretres.2009.10.005 
manuscript submitted to Geochemistry, Geophysics, Geosystems

1005

1006

1007

1008

1009

1010

1011

1012

1013

1014

1015

1016

1017

1018

1019

1020

1021

1022

1023

1024

1025

1026

1027

1028

1029

1030

1031

1032

Figure 1. Simplified terrane map of Anatolia including hypothesized suture zones (dashed lines) modified from Licht et al. (2017). İAES: İzmir-Ankara-Erzincan suture zone; IPS: Intra-Pontide suture zone.

Figure 2. Simplified geologic map of northwestern Anatolia (after Aksay et al., 2002; Duru \& Aksay, 2002; Gedik \& Aksay, 2002; Şahin et al., 2019; Timur \& Aksay, 2002; Turhan, 2002). See Figure 1 for location. Note that some published Karakaya Complex samples are west of the displayed map area.

Figure 3. Outcrops and isotopic ages of Devonian through Eocene plutons. Jurassic metamorphic rocks, Neoproterozoic to Ordovician crystalline basement, and southern CSB Late Cretaceous volcaniclastics are included (see Ocakoğlu et al., 2018; Duru \& Aksay, 2002; Gedik \& Aksay, 2002). Adapted from Akdoğan et al. (2017), Ersoy, Akal, et al. (2017), and Okay \& Nikishin (2015) and references therein.

Figure 4. Simplified Upper Cretaceous through Eocene lithostratigraphic diagram of the Central Sakarya Basin showing formation names and ages, and sample locations. The measured sections, stratigraphic age constraints, and interpreted depositional environments are from Ocakoğlu et al. (2018). Measured sections are schematically oriented in space; see Figure 2 for measured section locations. Grain size: Sh: shale; Ss: sandstone; Cg: conglomerate.

Figure 5. Detrital zircon age spectra characterizing potential sediment sources displayed as probability density functions (black lines) and optimized fixed bandwidth kernel density estimates (black lines and color shading). The Pontides volcanic arc ages are from a published compilation of pluton zircon U-Pb ages from the central and eastern Pontides. The Karakaya Complex samples are from Triassic sedimentary rocks and one modern river sample draining the İzmir-Ankara-Erzincan suture zone. The Central Sakarya Basement compilation includes bedrock and metasedimentary zircon $\mathrm{U}-\mathrm{Pb}$ ages. See Table 1 for data sources.

Figure 6. Detrital zircon age spectra from Central Sakarya Basin (CSB) and Sarıcakaya Basin (SB) detrital zircon samples grouped by basin phase (see main text); Phase 3 is split into CSB and SB groups. Data are displayed as probability density functions (black lines) and optimized 
1033 fixed bandwidth kernel density estimates (black lines and color shading). See Table 1 for data 1034 sources.

1035 Figure 7. Ternary diagrams of sandstone modal composition from the CSB. Samples are 1036 grouped by the sedimentary basin phases discussed in the text. Poles: Qt: total quartz; Qm: 1037 monocrystalline quartz; F: feldspar; L: lithics; Lm: metamorphic lithics; Ls: sedimentary lithics; 1038 Lv: volcanic lithics; Lt: total lithics ( $\mathrm{L}+$ polycrystalline quartz).

1039 Figure 8. Probability density functions (black lines) and optimized fixed bandwidth kernel 1040 density estimates (black lines and shading) of all bedrock, modern, and detrital zircon ages 1041 grouped by basement terrane, basin, and stratigraphic age. See main text for discussion.

1042 Figure 9. All 150 to $30 \mathrm{Ma}$ detrital zircon U-Pb ages from all SB and CSB samples are displayed 1043 as a histogram (1 Myr bins) and probability density function. The chronostratigraphic chart and 1044 depositional environments of the CSB and SB are after Ocakoğlu et al. (2018) and Mueller et al. 1045 (2019), respectively. Shading highlights the three sedimentary basin phases discussed in the text.

1046 Figure 10. Schematic diagram of multi-phase collision scenarios (inspired by Darin et al., 2018; 1047 Di Rosa et al., 2019; Göncüoğlu et al., 2014). (a) Tavşanlı Zone slab breakoff. (b) Relict basin 1048 closure between the Sakarya (SKZ) and Istanbul (IST) Zones in the north and/or the Tavşanlı 1049 Zone (TVZ) and Afyon Zone or Tauride terrane (AF-TAU) in the south. (c) Subduction and 1050 underthrusting of progressively thicker Tavşanlı Zone continental lithosphere.

1051 Table 1. New and published samples, units, ages, groups, sample types, and sources. DZ: detrital 1052 zircon; SP: sandstone petrography. Data sources: 1: Ustaömer et al., 2012; 2: Ustaömer et al., 1053 2016; 3: Campbell, 2017; 4: Ocakoğlu et al., 2018; 5: Schleiffarth et al., 2018 and references 1054 therein; 6: Mueller et al., 2019; 7: this study. 
Figure 1. 

Figure 2. 
N Sea of Marmara

$\uparrow$

N

ake iznik

North Anatolian Fault Zone

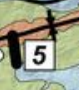

14

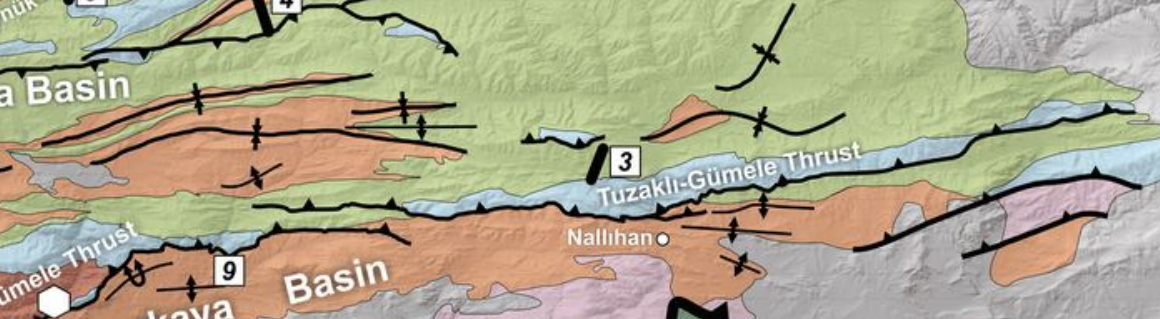

(4) Bilecik 3
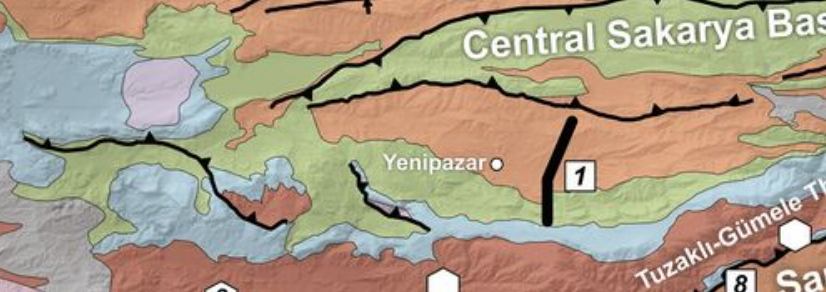

F, 19 Basin

7

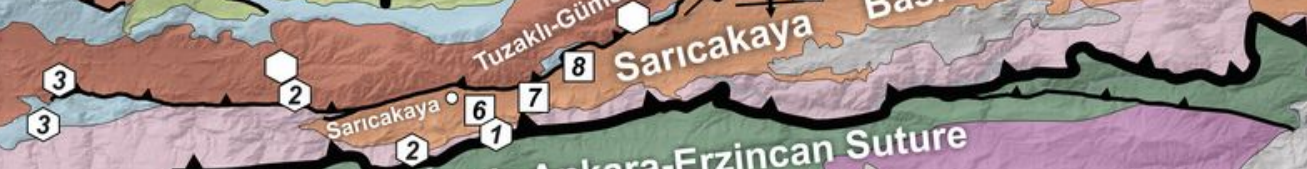

12 izmir-Ankara-Erzincan Suture

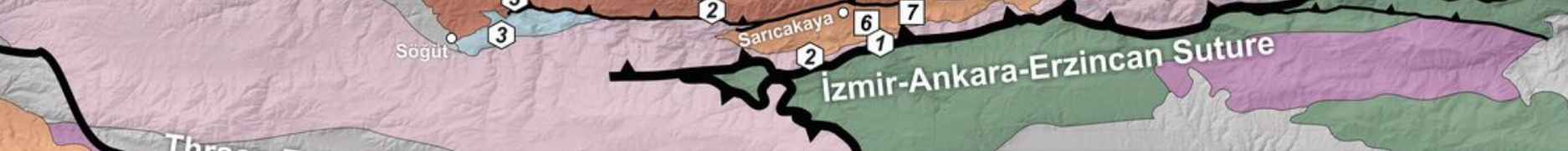

Kilometers

\section{$29^{\circ} 30^{\prime} \mathrm{E}$}

Geologic Units:

$\square$ Paleogene sedimentary and igneous

$\square$ Cretaceous sedimentary and igneous

$\square$ Cretaceous ophiolite and mélange

$\square$ Jurassic sedimentary and igneous

$\square$ Permian-Triassic Karakaya Complex

Central Sakarya basement,

incl. Carboniferous granitoids

Tavşanli Zone basement
Thrace-Eskişehir Faukt

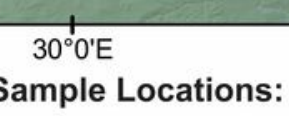

Central Sakarya Basin

- Measured sections from Ocakoğlu et al. (2018)

1 Yenipazar section

2 Tarakı section

3 Nallıhan section

4 Okçular section

5 Göynük section
Measured sections from

Mueller et al. (2019)

6. Mayıslar section

7 Iğdır section

8 Kapıkaya section

9 Ozanköy section
Provenance Sources

$\checkmark$ This study

(1) Published samples 1: Campbell (2017), 2: Mueller et al. (2019),
3: Ustaömer et al. (2012), 4: Ustaömer et al. (2016)
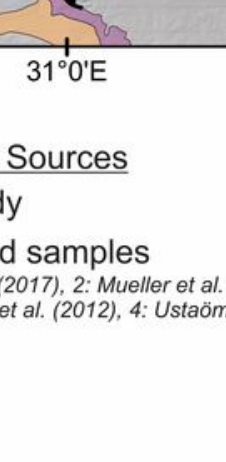

$31^{\circ} 30^{\circ}$

Symbols:

\# Anticline

+ Syncline

C City

$\leftrightharpoons$ Strike-slip fault

Thrust fault

or suture 
Figure 3. 


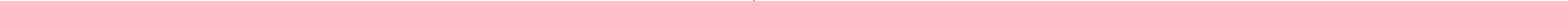


Figure 4. 


\section{Yenipazar Section}

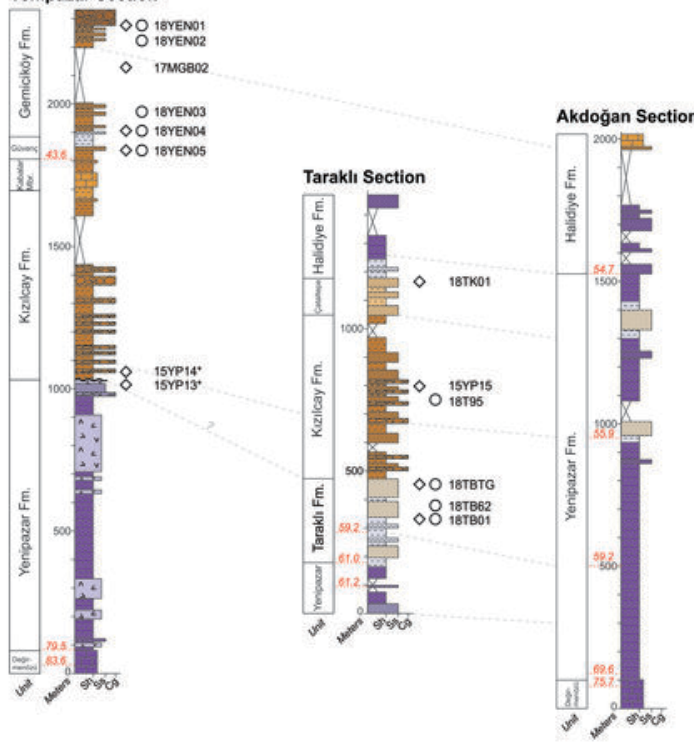

Stratigraphic age constraints from Ocakoglu ot al. (2018)

_. 65.0 - Biostratigraphic age

$78.5 \pm 1.6$ Zircon U.Pb age

\section{Samples}

$\checkmark$ Detrital zircon

O Sandstone petrography "Converal, soit conogy ent, nets

Schematic orientation of stratigraphic columns

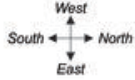

Depositional environments
from Ocakoglu et al. (2018)
Alluvial
Fluvial
Lagoonal
Shoreface
Delta
Carbonate shelf
Shelf to prodelta
Pyroclastic
Submarine fan
Pelagic / deep marine

\section{Nallihan Section}

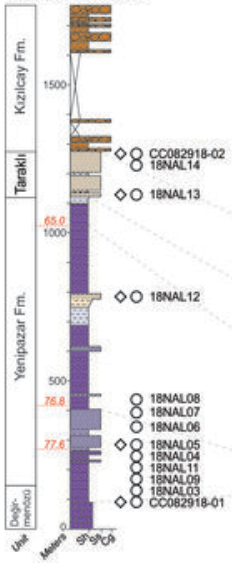

\section{Okçular Section}

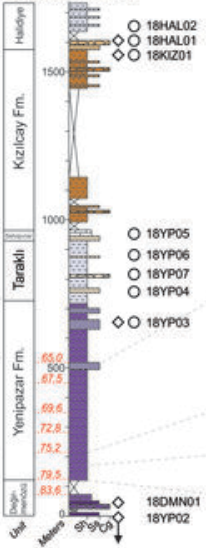

Göynūk Section

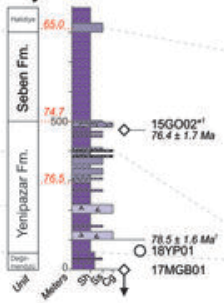

Ismaller Section

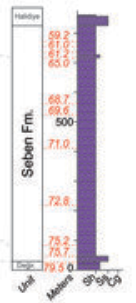


Figure 5. 

Figure 6. 

Figure 7. 
Figure 8. 
Figure 9. 
Ma U-Pb Composite Stratigraphic Columns



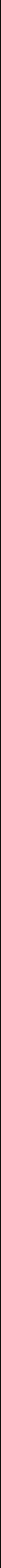


Figure 10. 


\begin{tabular}{|c|c|c|}
\hline Sample & Unit & Age \\
\hline \multicolumn{3}{|c|}{ Central Sakarya Basin } \\
\hline \multicolumn{3}{|c|}{ Yenipazar Section } \\
\hline $15 Y \mathrm{Y} 13$ & Yenipazar Fm & Maastrichtian \\
\hline $15 Y \mathrm{Y} 14$ & K1zılçay Fm & Paleocene \\
\hline 18YEN05 & Kızılçay Fm & Paleocene-lower Eocene \\
\hline 18YEN04 & Güvenç Fm & Lutetian \\
\hline 18YEN03 & Güvenç Fm & Lutetian-Bartonian \\
\hline 17MGB02 & Gemiciköy Fm & Upper Lutetian-Lower Bartonian \\
\hline 18YEN02 & Gemiciköy Fm & Bartonian-Priabonian \\
\hline 18YEN01 & Gemiciköy Fm & Bartonian-Priabonian \\
\hline \multicolumn{3}{|l|}{ Taraklı Section } \\
\hline 18TB01 & Tarakl1 Fm & Paleocene-lower Eocene \\
\hline 18TB62 & Tarakl1 Fm & Paleocene-lower Eocene \\
\hline 18TBTG & Taraklı Fm & Paleocene-lower Eocene \\
\hline $18 \mathrm{~T} 95$ & Kızılçay Fm & Paleocene-lower Eocene \\
\hline $15 Y P 15$ & Kızılçay Fm & Paleocene-lower Eocene \\
\hline $18 \mathrm{TK} 01$ & Çataltepe Fm & Paleocene-lower Eocene \\
\hline \multicolumn{3}{|c|}{ Nallihan Section } \\
\hline CC082918-01 & Yenipazar Fm & Cenomanian-Turonian \\
\hline 18NAL03 & Yenipazar Fm & Lower Campanian \\
\hline 18NAL09 & Yenipazar Fm & Lower Campanian \\
\hline 18NAL11 & Yenipazar Fm & Lower Campanian \\
\hline 18NAL04 & Yenipazar Fm & Lower Campanian \\
\hline 18NAL05 & Yenipazar Fm & Middle Campanian \\
\hline 18NAL06 & Yenipazar Fm & Middle Campanian \\
\hline 18NAL07 & Yenipazar Fm & Middle Campanian \\
\hline 18NAL08 & Yenipazar Fm & Middle Campanian \\
\hline 18NAL12 & Yenipazar Fm & Upper Campanian-Maastrichtian \\
\hline 18NAL13 & Taraklı Fm & Upper Campanian-Maastrichtian \\
\hline 18NAL14 & Taraklı Fm & Upper Campanian-Maastrichtian \\
\hline CC082918-02 & Tarakl1 Fm & Upper Campanian-Maastrichtian \\
\hline \multicolumn{3}{|c|}{ Okçular Section } \\
\hline 18YP02 & Değirmenözü Fm & Santonian-Campanian \\
\hline 18DMN01 & Değirmenözü Fm & Santonian \\
\hline 18YP03 & Yenipazar Fm & Lower Paleocene \\
\hline 18YP04 & Taraklı Fm & Lower-middle Paleocene \\
\hline 18YP07 & Tarakl1 Fm & Lower-middle Paleocene \\
\hline 18YP06 & Tarakl1 Fm & Lower-middle Paleocene \\
\hline 18YP05 & Taraklı Fm & Lower-middle Paleocene \\
\hline 18KIZ01 & Kızılçay Fm & Paleocene-lower Eocene \\
\hline 18HAL01 & Halidiye Fm & Lutetian \\
\hline 18HAL02 & Halidiye Fm & Lutetian \\
\hline \multicolumn{3}{|c|}{ Göynük Section } \\
\hline 17MGB01 & Değirmenözü Fm & Middle Cretaceous \\
\hline 18YP01 & Değirmenözü Fm & Lower Campanian \\
\hline $15 \mathrm{GO} 02$ & Yenipazar Fm & Middle-upper Campanian \\
\hline
\end{tabular}




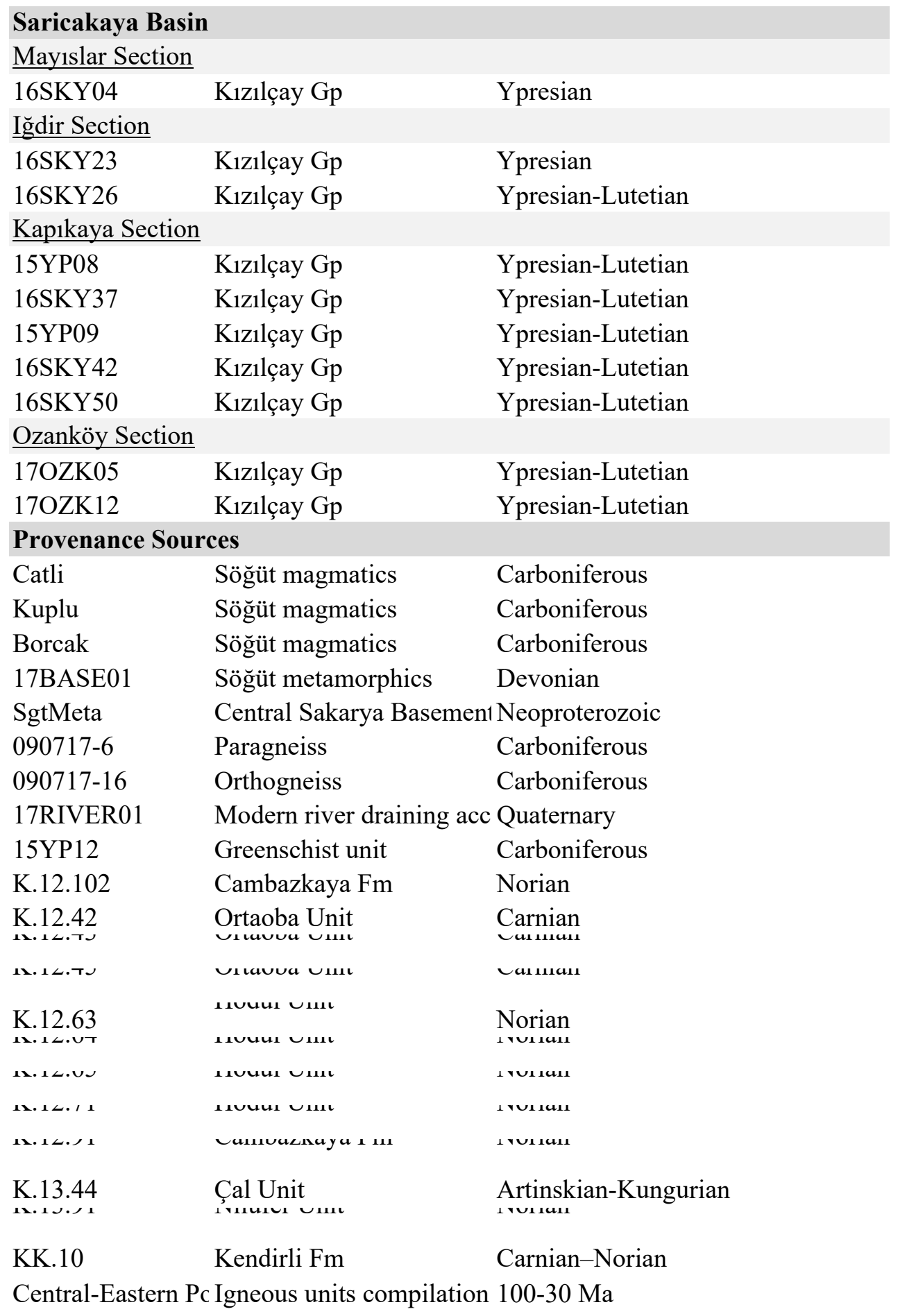


Middle Campanian-lower Eocene Middle Campanian-lower Eocene Middle Campanian-lower Eocene Middle-upper Eocene Middle-upper Eocene

Middle-upper Eocene Middle-upper Eocene Middle-upper Eocene

Middle Campanian-lower Eocene Middle Campanian-lower Eocene Middle Campanian-lower Eocene Middle Campanian-lower Eocene Middle Campanian-lower Eocene Middle Campanian-lower Eocene

Turonian-lower Campanian Turonian-lower Campanian Turonian-lower Campanian Turonian-lower Campanian Turonian-lower Campanian Middle Campanian-lower Eocene Middle Campanian-lower Eocene Middle Campanian-lower Eocene Middle Campanian-lower Eocene Middle Campanian-lower Eocene Middle Campanian-lower Eocene Middle Campanian-lower Eocene Middle Campanian-lower Eocene

Turonian-lower Campanian

Turonian-lower Campanian Middle Campanian-lower Eocene Middle Campanian-lower Eocene Middle Campanian-lower Eocene Middle Campanian-lower Eocene Middle Campanian-lower Eocene Middle Campanian-lower Eocene Middle-upper Eocene Middle-upper Eocene

Turonian-lower Campanian Turonian-lower Campanian Middle Campanian-lower Eocene
DZ 3

$\mathrm{DZ}$

DZ, SP 7

DZ, SP 7

SP 7

DZ 7

SP 7

DZ, SP 7

DZ, SP 7

SP 7

DZ, SP 7

SP 7

DZ 7

DZ 7

DZ, SP 7

SP 7

SP 7

SP 7

SP 7

DZ, SP 7

SP 7

SP 7

SP 7

DZ, SP 7

DZ, SP 7

SP 7

DZ, SP 7

DZ 7

DZ 7

DZ, SP 7

SP 7

SP 7

SP 7

SP 7

$\mathrm{DZ}, \mathrm{SP} \quad 7$

DZ, SP 7

SP 7

$\begin{array}{ll}\mathrm{DZ} & 7\end{array}$

SP 7

DZ 3,4 
Lower-middle Eocene

Lower-middle Eocene

Lower-middle Eocene

Lower-middle Eocene

Lower-middle Eocene

Lower-middle Eocene

Lower-middle Eocene

Lower-middle Eocene

Lower-middle Eocene

Lower-middle Eocene

Central Sakarya Basement

Central Sakarya Basement

Central Sakarya Basement

Central Sakarya Basement

Central Sakarya Basement

Central Sakarya Basement

Central Sakarya Basement

İzmir-Ankara-Erzincan Suture

Karakaya Complex

Karakaya Complex

Karakaya Complex

Karakaya Complex

Karakaya Complex

Karakaya Complex

Karakaya Complex

Karakaya Complex

Karakaya Complex

Karakaya Complex

Karakaya Complex

Karakaya Complex

Karakaya Complex

Central-Eastern Pontides Arc
DZ

DZ

6

DZ

6

DZ

3

DZ

6

DZ

3

DZ

6

DZ

6

DZ

6

DZ

6

Bedrock

Bedrock 1

Bedrock 1

Metased. DZ 6

Bedrock 1

Metased. DZ 7

Bedrock 7

Modern DZ 6

Bedrock 3

DZ

DZ

บะ

Le

บe

Le

บe

Le

บe

DZ

2

Metased. DZ

DZ

Bedrock 5 